\title{
Sources and physicochemical characteristics of black carbon aerosol from the southeastern Tibetan Plateau: internal mixing enhances light absorption
}

\author{
Qiyuan Wang $^{1}$, Junji Cao ${ }^{1,2}$, Yongming Han ${ }^{1,3}$, Jie Tian $^{4}$, Chongshu Zhu ${ }^{1}$, Yonggang Zhang ${ }^{1}$, Ningning Zhang ${ }^{1}$, \\ Zhenxing Shen ${ }^{4}$, Haiyan $\mathrm{Ni}^{1}$, Shuyu $\mathrm{Zhao}^{1}$, and Jiarui $\mathrm{Wu}^{1}$ \\ ${ }^{1}$ Key Laboratory of Aerosol Chemistry and Physics, State Key Laboratory of Loess and Quaternary Geology, \\ Institute of Earth Environment, Chinese Academy of Sciences, Xi'an, 710061, China \\ ${ }^{2}$ Institute of Global Environmental Change, Xi' an Jiaotong University, Xi'an, 710049, China \\ ${ }^{3}$ School of Human Settlements and Civil Engineering, Xi' an Jiaotong University, Xi' an, 710049, China \\ ${ }^{4}$ Department of Environmental Science and Engineering, School of Energy and Power Engineering, Xi' an Jiaotong \\ University, Xi' an, 710049, China
}

Correspondence: Qiyuan Wang (wangqy@ieecas.cn) and Junji Cao (cao@loess.llqg.ac.cn)

Received: 28 August 2017 - Discussion started: 21 November 2017

Revised: 15 February 2018 - Accepted: 6 March 2018 - Published: 5 April 2018

\begin{abstract}
Black carbon (BC) aerosol has important effects on the climate and hydrology of the Tibetan Plateau (TP). An intensive measurement campaign was conducted at Lulang ( $3300 \mathrm{~m}$ a.s.l. - above sea level), southeastern TP, from September to October 2015, to investigate the sources and physicochemical characteristics of refractory $\mathrm{BC}(\mathrm{rBC})$ aerosol. The average $\mathrm{rBC}$ mass concentration was $0.31 \pm 0.55 \mu \mathrm{g} \mathrm{m}^{-3}$, which is higher than most prior results for $\mathrm{BC}$ on the TP. A clear diurnal cycle in $\mathrm{rBC}$ showed high values in the morning and low values in the afternoon. A bivariate polar plot showed that $\mathrm{rBC}$ loadings varied with wind speed and direction, which also reflected the dominant transport direction. The estimated net surface $\mathrm{rBC}$ transport intensity was $+0.05 \pm 0.29 \mu \mathrm{g} \mathrm{s}^{-1} \mathrm{~m}^{-2}$, indicating stronger transport from outside the TP compared with its interior. Cluster analysis and a concentration-weighted trajectory model connected emissions from north India to the high rBC loadings, but the effects of internal TP sources should not be overlooked. The average mass median diameter (MMD) of rBC was $160 \pm 23 \mathrm{~nm}$, with smaller MMDs on rainy days $(145 \mathrm{~nm})$ compared with non-rainy days $(164 \mathrm{~nm})$. The average number fraction of thickly coated $\mathrm{rBC}\left(F_{\mathrm{rBC}}\right)$ was $39 \pm 8 \%$, and it increased with the $\mathrm{O}_{3}$ mixing ratios from 10:00 to 14:00 LT, indicating that photochemical oxidation played a role in forming $\mathrm{rBC}$ coatings. The average $\mathrm{rBC}$ absorption enhancement $\left(E_{\mathrm{abs}}\right)$ was estimated to
\end{abstract}

be 1.9, suggesting that light absorption by coated $\mathrm{rBC}$ particles was greater than for uncoated ones. The $E_{\text {abs }}$ was strongly positively correlated with the $F_{\mathrm{rBC}}$, indicating an amplification of light absorption for internally mixed rBC. For $\mathrm{rBC}$ cores $<170 \mathrm{~nm}, E_{\text {abs }}$ was negatively correlated with MMD, but it was nearly constant for $\mathrm{rBC}$ cores $>170 \mathrm{~nm}$. Our study provides insight into the sources and evolution of rBC aerosol on the TP, and the results should be useful for improving models of the radiative effects of carbonaceous aerosols in this area.

\section{Introduction}

The Tibetan Plateau (TP) is the world's largest high-elevation region. It holds the largest ice mass on the planet outside the polar regions and is sometimes called the Earth's "Third Pole" (Yao et al., 2008). The snow and associated glacial meltwater on the TP provides fresh water for drinking and irrigation for more than 1 billion people downstream (Immerzeel et al., 2010). The TP exerts significant thermal and dynamic impacts on hydrological processes in South and East Asia. For example, changes in the area covered by glaciers and snowpack on the TP affect the heat fluxes and water exchange between the atmosphere and the earth's surface, and that, in turn, affects the atmospheric circulation 
associated with the Asian Monsoon System (Lau and Kim, 2006). Glaciers can be sensitive to climate change (Dyurgerov and Meier, 2000), and recent observations have shown a continuing retreat in Tibetan glaciers (e.g., Xu et al., 2009; Yao et al., 2012; Zhang et al., 2012; Loibl et al., 2014; Kang et al., 2015; Huintjes et al., 2016; Ke et al., 2017). For instance, Yao et al. (2012) reviewed the status of glaciers on the $\mathrm{TP}$ and surrounding areas over the past 30 years. These authors reported systematic differences from region to region, and their study showed that the greatest reduction in glacial length and area and the most negative mass balance occurred in the Himalayas (excluding the Karakorum).

The past few decades have witnessed rapid growth in the human population and industrialization in South and East Asia, and this growth has led to widespread air pollution (Vadrevu et al., 2014; Cao, 2017). An important component of this pollution is the black carbon (BC) aerosol, the lightabsorbing, refractory material produced mainly through the incomplete combustion of fossil fuels and biomass (Bond et al., 2013). In addition to its effects on air quality, BC plays a unique and important role in the Earth's climate system due to its impacts on solar radiation, clouds, and snow albedo (Bond et al., 2013). Indeed, it has been suggested that $\mathrm{BC}$ is the second largest contributor to anthropogenic radiative forcing after carbon dioxide due to its strong absorption of solar radiation (Jacobson, 2001; Ramanathan and Carmichael, 2008; Bond et al., 2013). Furthermore, BC aerosol can alter atmospheric circulation patterns, accelerate snowmelt, and cause glaciers to retreat (Xu et al., 2009).

Geographically, the TP is surrounded by South and East Asia where BC sources are strong (Zhang et al., 2009), and the TP has become impacted by these high-BC source areas due to the general circulation patterns (Cao et al., 2010; Lu et al., 2012; S. Zhao et al., 2017). For example, Lu et al. (2012) found that BC loadings in the Himalayas and TP increased by $41 \%$ from 1996 to 2010 due to the influences of surrounding areas. Annually, on average, South and East Asia account for 67 and $17 \%$ of BC transported to the plateau, respectively. However, several recent studies showed that the impact of internal Tibetan sources (e.g., yak dung combustion by local residents) on the atmosphere of the TP should not be overlooked (Chen et al., 2015; Li et al., 2016a; X. Zhang et al., 2017). In the past few decades, a number of field campaigns conducted on the TP have investigated the concentrations, sources, and spatial and temporal variations of $\mathrm{BC}$ aerosol (e.g., Engling et al., 2011; Cong et al., 2015; M. Wang et al., 2016; Zhu et al., 2016; Wang et al., 2017; Z. Zhao et al., 2017). Recently, research has begun to focus on the light absorption characteristics of $\mathrm{BC}$ particles in the atmosphere and snow (Li et al., 2016b, c; Y. Zhang et al., 2017). These studies have been helpful for improving estimates of the radiative forcing of $\mathrm{BC}$ in the atmosphere of the TP.

Although some aerosol-related field studies have been conducted on the TP, the $\mathrm{BC}$ measurements were mainly made using online or offline filter-based techniques (e.g., aethalometer, thermal/optical reflectance method, and multiangle absorption photometer) (e.g., Engling et al., 2011; Marinoni et al., 2010; Wan et al., 2015; Zhu et al., 2016; Li et al., 2017). These techniques are based on the bulk particle deposition onto the filters, and they cannot provide high time resolution information on of $\mathrm{BC}$ size and mixing state. This is a significant limitation of the filter-based methods because the optical properties of the $\mathrm{BC}$ aerosol are related to the particles' chemical and microphysical characteristics, including their size and mixing state. For instance, Liu et al. (2015) reported direct evidence of substantial field-measured BC absorption enhancement ( $\left.E_{\mathrm{abs}}\right)$ in an urban area, and this was strongly dependent on the internal mixing of BC. Peng et al. (2016) used a novel environmental chamber to quantify the aging and variations in the morphology and optical properties of BC particles from Beijing, China, and Houston, United States. That study showed that BC particles initially changed from a fractal to spherical morphology with little change in absorption followed by growth into compact particles with large $E_{\text {abs }}$.

Accurate information on the physicochemical characteristics of BC can improve our understanding of anthropogenic climate impacts on the TP, but there is still a lack of high time resolution measurements on the size and mixing state of $\mathrm{BC}$ in this region. This deficiency has led to considerable uncertainty in the calculations of $\mathrm{BC}$ direct radiative forcing over TP (He et al., 2014). In this study, we used a singleparticle soot photometer (SP2) and a photoacoustic extinctiometer (PAX) to determine the mass concentrations, size distributions, mixing states, and light absorption properties of refractory $\mathrm{BC}(\mathrm{rBC})$ from the southeastern part of the TP. Various terms have been used in the literature for the most refractory and light-absorbing components of carbonaceous aerosols, and these have been based on the experimental measurement techniques (Bond et al., 2013). Here the term rBC is used exclusively in reference to SP2 measurements, while eBC (equivalent $\mathrm{BC}$ ) and $\mathrm{EC}$ (elemental carbon) refer to the data from the optical absorption method and the thermal heating and optical absorption techniques, respectively, used in other studies (Petzold et al., 2013). The primary objectives of this study were (1) to investigate the effects of meteorology on $\mathrm{rBC}$ and identify probable source regions responsible for the high $\mathrm{rBC}$ loadings; (2) to characterize the $\mathrm{rBC}$ size distributions and the evolution of $\mathrm{rBC}$ mixing state; and (3) to derive the $\mathrm{rBC} E_{\mathrm{abs}}$ and evaluate the factors that affect it.

\section{Methodology}

\subsection{Sampling site}

Physicochemical and optical properties of $\mathrm{rBC}$ aerosol were measured in samples collected from a remote area of Lulang, which is located on the southeastern part of the TP (Fig. 1). An intensive measurement campaign was conducted from 


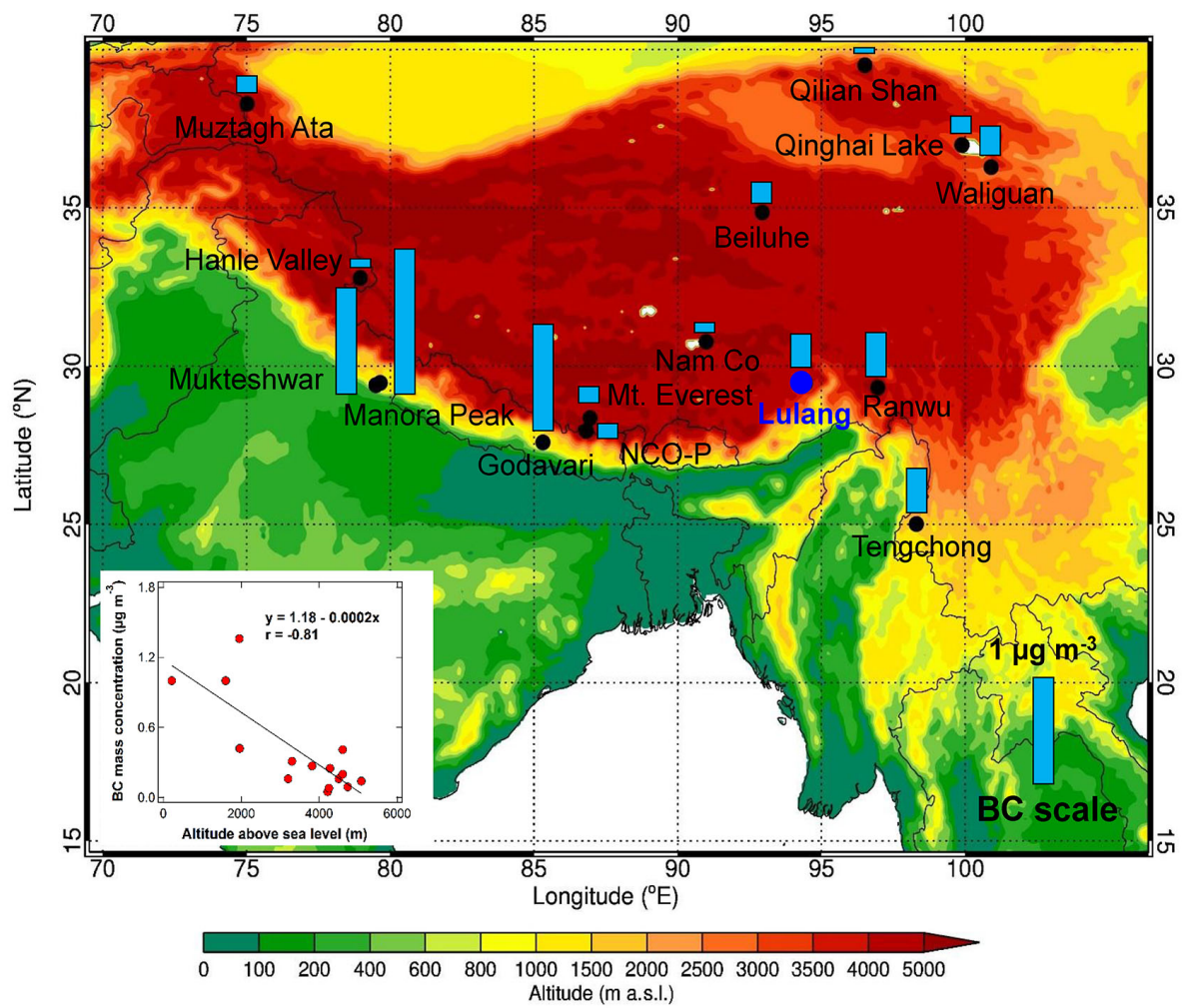

Figure 1. Black carbon concentrations $\left(\mu \mathrm{g} \mathrm{m}^{-3}\right)$ measured at 15 sampling sites in the Himalayas and on the Tibetan Plateau based on the measurements from this study (blue solid circles) and other studies (black solid circles) from Ma et al. (2003), Pant et al. (2006), Marinoni et al. (2010), Stone et al. (2010), Babu et al. (2011), Engling et al. (2011), Zhao et al. (2012), Li et al. (2017), Wan et al. (2015), Wang et al. (2015a), M. Wang et al. (2016), Zhu et al. (2016), and Raatikainen et al. (2017). More detailed information concerning these studies is summarized in Table S1. The inset is a scatter plot of the mass concentrations of BC versus the altitude of each sampling site. The map in the figure was drawn using the Weather Research and Forecasting (WRF) model.

17 September to 31 October 2015 on the dormitory rooftop of the Southeast Tibet Integrated Observation and Research Station for the Alpine Environment, Chinese Academy of Sciences $\left(94.44^{\circ} \mathrm{E}, 29.46^{\circ} \mathrm{N} ; \sim 3300 \mathrm{~m}\right.$ a.s.l. - above sea level). There were no major anthropogenic sources near the sampling site.

\subsection{Data collection}

\subsubsection{Quantification of rBC mass, size, and mixing state}

A single-particle soot photometer manufactured by Droplet Measurement Technologies (Boulder, CO, USA) was used to determine the mass, size, and mixing state of $\mathrm{rBC}$ particles. The operation and principles of the SP2 have been described in detail elsewhere (Schwarz et al., 2006). Briefly, a highintensity intra-cavity Nd:YAG laser operating at wavelength of $1064 \mathrm{~nm}$ heated an individual rBC-containing particle to its incandescence temperature $(\sim 4000 \mathrm{~K})$, which then emitted thermal radiation that was detected optically. Simultaneously, the laser light scattered by the rBC-containing particle was detected elastically. The intensity of the incandescence signal is proportional to the mass of $\mathrm{rBC}$ contained in the particle, but it is not affected by the particle morphology or the presence of non-refractory matter (Slowik et al., 2007). In this study, the SP2 was calibrated with a standard fullerene soot sample (Lot F12S011, Alfa Aesar, Inc., Ward Hill, MA, USA). A linear relationship was established between the peak intensity of the incandescence signal and the rBC mass. For this procedure, fullerene soot particles generated by an atomizer (Model 9302, TSI Inc., Shoreview, MN, USA) were passed through a diffusion silica-gel dryer, and then they were separated by size with a differential mobility analyzer (Model 3080, TSI Inc.) before entering the SP2 instrument. The corresponding fullerene soot masses were estimated using the effective density data provided by Gysel et al. (2011). More information concerning the SP2 calibration procedure may be found in Wang et al. (2014).

The measured $\mathrm{rBC}$ mass was converted to the volume equivalent diameter (VED) by assuming $\mathrm{rBC}$ particles were solid spheres with a density of $1.8 \mathrm{~g} \mathrm{~cm}^{-3}$ (Bond and Bergstrom, 2006). The detection efficiency of the SP2 drops off for $\mathrm{rBC}$ core sizes $<\sim 70 \mathrm{~nm}$, and the signal becomes saturated for sizes $>\sim 600 \mathrm{~nm}$. Based on a mono-modal lognormal fit for the mass size distributions as described in 
Sect. 3.3.1 below (Fig. S1 in the Supplement), the reported $\mathrm{rBC}$ mass concentrations in this study were scaled up by a factor of $\sim 1.1$ to compensate for the losses outside of the SP2 detection range. The uncertainty of the SP2 mass measurements was $\sim 20 \%$, which was estimated by propagating the uncertainties caused by the SP2 response to ambient rBC mass $(\sim 15 \%$; Laborde et al., 2012), sample flow $(\sim 10 \%)$, and estimates of the rBC mass beyond the SP2 detection range $(\sim 10 \%)$.

A major advantage of the SP2 is that it has the capability of determining the rBC mixing state (Schwarz et al., 2006). Freshly emitted $\mathrm{rBC}$ can be internally mixed with non-rBC materials through the process of gas-particle conversion. When the laser beam in the SP2 heats an internally mixed $\mathrm{rBC}$ particle, the coatings are preferentially evaporated, and that causes a decrease in the intensity of the scattering signal. After that, the rBC core starts to vaporize and that produces a peak in the incandescence signal. Therefore, there is a lag time between the peaks of the scattering and incandescence signals. These lag times can be used to characterize the internal mixing of rBC (McMeeking et al., 2011; Huang et al., 2012; Wu et al., 2016). Figure S2 shows that the lag times exhibited a bimodal distribution, with $\sim 2 \mu$ s separating two distinct populations. The rBC-containing particles with a lag time $>2 \mu$ s were considered to have substantial coatings, and those particles were denoted as thickly coated. In contrast, the $\mathrm{rBC}$-containing particles with lag times $<2 \mu$ s were classified as uncoated or thinly coated. Here the number fraction of thickly coated $\mathrm{rBC}\left(F_{\mathrm{rBC}}\right)$ was used to represent the degree of internal mixing of the $\mathrm{rBC}$ particles, and it was calculated by dividing the number of thickly coated $\mathrm{rBC}$ particles by the total number of $\mathrm{rBC}$ particles. As there were no incandescence signals detected for small particles and the scattering signal became saturated for large coated $\mathrm{rBC}$ particles, the $\mathrm{rBC}$ core sizes used to evaluate internal mixing were limited to $\sim 70$ to $300 \mathrm{~nm}$ VED. An examination of the number size distribution of $\mathrm{rBC}$ shows that this was not a critical limitation in the following analysis because that size range contained the vast majority of the detected $\mathrm{rBC}$ particles (see Fig. S1).

\subsubsection{Particle light absorption measurements}

A photoacoustic extinctiometer operating at a wavelength of $870 \mathrm{~nm}$ (PAX 870 , Droplet Measurement Technologies) was used to measure the particles' light absorption coefficients $\left(b_{\mathrm{abs}}\right)$ based on intra-cavity photoacoustic technology. The light-absorbing particles were heated by the laser beam in the acoustic chamber. This heating produced a pressure wave that was detected with a sensitive microphone. The $\mathrm{PAX}_{870}$ can also measure the particles' light scattering coefficient $\left(b_{\text {scat }}\right)$ simultaneously with a wide-angle integrating reciprocal nephelometer in the scattering chamber. Before and during sampling, the light scattering and absorption of the $\mathrm{PAX}_{870}$ were calibrated with ammonium sulfate and freshly generated propane soot, respectively. The light extinction coefficient $\left(b_{\text {ext }}=b_{\text {scat }}+b_{\text {abs }}\right)$ can be calculated from the laser power of the $\mathrm{PAX}_{870}$. Thus a correction factor can be established from the relationship between the calculated $b_{\text {abs }}\left(=b_{\text {ext }}-b_{\text {scat }}\right)$ and the measured $b_{\text {abs }}$. The $b_{\text {ext }}$ is calculated using the following formula:

$b_{\mathrm{ext}}=-\frac{1}{0.354} \times \ln \frac{I}{I_{0}} \times 10^{6}\left[\mathrm{Mm}^{-1}\right]$,

where 0.354 is the path length of the laser beam through the cavity in $\mathrm{m} ; 10^{6}$ is a conversion factor used to express $b_{\text {ext }}$ in $\mathrm{Mm}^{-1}$; $I$ is the laser power during calibration $(\mathrm{mW})$, and $I_{0}$ is the average laser power before and after calibration. A linear relationship was established between the extinctionminus-scattering coefficients and the measured $b_{\text {abs. }}$. The slope of the regression line, that is, the correction factor, was then used as the new calibration factor for absorption. In this study, the same steps for the absorption calibration were repeated until the correction factor was stable within $\sim 10 \%$. Different concentration gradients of freshly generated propane soot were used to give an absorption reading of $\sim 10$ to $16700 \mathrm{Mm}^{-1}$ for absorption calibration (Fig. S3). The uncertainty of the PAX for absorption measurements was estimated to be $\sim 15 \%$ based on the variations of $b_{\mathrm{abs}}$ caused by the noise during the sampling period. It is worth noting that the $b_{\text {scat }}$ produced by freshly generated propane soot particles has a substantial contribution to $b_{\text {ext }}$, while ammonium sulfate is the only material that generates $b_{\text {scat }}$. Thus, the scattering was calibrated before the $b_{\text {abs }}$ calibration using the same procedures as for the absorption calibration (Fig. S3). In this study, sampled particles passed through a Nafion ${ }^{\circledR}$ dryer (MD-110-48S; Perma Pure, Inc., Lakewood, NJ, USA) before entering the $\mathrm{PAX}_{870}$. As shown in Fig. S4, the light-absorbing particle loss for this type of Nafion tube may be $\sim 10 \%$. Thus, the $b_{\text {abs }}$ values were scaled up by a factor of $\sim 1.1$ to compensate for the losses. Moreover, about $15 \%$ of the total number of $b_{\text {abs }}$ measurements were excluded because the values were lower than the minimum detection limit of $\operatorname{PAX}_{870}\left(1.0 \mathrm{Mm}^{-1}\right)$.

\subsubsection{Complementary data}

A portable DustTrak ${ }^{\mathrm{TM}}$ aerosol monitor (Model 8530, TSI Inc., Shoreview, MN, USA) was used to measure the mass concentrations of total suspended particulate matter (TSP). Hourly ozone $\left(\mathrm{O}_{3}\right)$ was measured using a UV-based dual beam $\mathrm{O}_{3}$ monitor (2B Technology model 205, CO, USA). Wind speed and wind direction were measured hourly with the use of an automatic weather station installed at the Southeast Tibet Integrated Observation and Research Station for the Alpine Environment, Chinese Academy of Sciences. The planetary boundary layer (PBL) heights were obtained from the European Centre for Medium-range Weather Forecasts (ECMWF). These can be downloaded from ERAInterim (January 1979-present) reanalysis datasets at http: 
//apps.ecmwf.int/datasets. The spatial distribution of the BC column mass density was retrieved from the Modern-Era Retrospective analysis for Research and Applications version 2 (MERRA-2) using the Goddard Earth Observing System Model, Version 5 (GEOS-5) with its Atmospheric Data Assimilation System, version 5.12.4 (https://giovanni.gsfc. nasa.gov/giovanni). True color images obtained from the Moderate Resolution Imaging Spectroradiometer (MODIS) on the Terra satellite were used to assess the pollution distributions visually on several selected days, and those images were downloaded from the website https://lance.modaps. eosdis.nasa.gov.

\subsection{Data analysis}

\subsubsection{Assessment of surface transport}

Hourly $\mathrm{rBC}$ concentrations and the corresponding wind data were used to estimate the surface transport of $\mathrm{rBC}$ at the $\mathrm{Lu}$ lang site using the following formula (White et al., 1976):

$f=\frac{1}{n} \sum_{j=1}^{n} C_{j} \times \mathrm{WS}_{j} \times \cos \theta_{j}$,

where $f$ is the surface transport intensity of $\mathrm{rBC}$ in units of $\mu \mathrm{g} \mathrm{s}^{-1} \mathrm{~m}^{-2}$ (that is, mass transported per unit time and area); $C_{j}$ and $\mathrm{WS}_{j}$ are the mean $\mathrm{rBC}$ concentrations $\left(\mu \mathrm{g} \mathrm{m}^{-3}\right)$ and wind speeds $\left(\mathrm{m} \mathrm{s}^{-1}\right)$ during the $j$ th observation hour, respectively; $\theta_{j}$ is the angle between wind direction and the north-south direction during the $j$ th observation hour; and $n$ is the total number of observation hours. Generally, strong winds favor the dispersion of air pollutants for local emission sources, whereas weak winds lead to accumulation. In contrast, for regional sources, strong winds can transport pollutants from upwind areas and cause high concentrations of pollutants downwind. Therefore, in this study, we viewed the surface flux intensity as a measure of the influence of regional transport in South Asia, and more specifically on the Lulang site using ground-based observations. Positive values for $f$ were considered indicative of transport from outside the TP (e.g., the Indo-Gangetic Plain, IGP, and Bangladesh), whereas negative values indicated transport from the interior of the TP.

\subsubsection{Cluster analysis of air-mass trajectories}

Three-day air mass trajectories calculated backwards in time were used to characterize the atmospheric transport of $\mathrm{rBC}$ to Lulang. Each trajectory was calculated for an arrival height of $150 \mathrm{~m}$ above ground. The trajectories were calculated hourly using the Hybrid Single-Particle Lagrangian Integrated Trajectory (HYSPLIT) model (Draxler and Rolph, 2003) developed by the Air Resource Lab (ARL) of the National Oceanic and Atmospheric Administration (NOAA). Because a large number of trajectories (887) retrieved for the entire campaign showed diverse pathways, a clustering procedure was used to establish representative pathways for the trajectories based on an angle-based distance statistics method. This was defined using the law of cosines from the following equations (Sirois and Bottenheim, 1995):

$$
\begin{aligned}
d_{12} & =\frac{1}{n} \sum_{i=1}^{n} \cos ^{-1}\left(0.5 \times \frac{A_{i}+B_{i}-C_{i}}{\sqrt{A_{i} B_{i}}}\right) \\
A_{i} & =\left(X_{1}(i)-X_{0}\right)^{2}+\left(Y_{1}(i)-Y_{0}\right)^{2} \\
B_{i} & =\left(X_{2}(i)-X_{0}\right)^{2}+\left(Y_{2}(i)-Y_{0}\right)^{2} \\
C_{i} & =\left(X_{2}(i)-X_{1}(i)\right)^{2}+\left(Y_{2}(i)-Y_{1}(i)\right)^{2},
\end{aligned}
$$

where $d_{12}$ is the mean angle between the two backward trajectories, which varies between 0 and $\pi ; X_{0}$ and $Y_{0}$ represent the position of the receptor site (Lulang in the present case); and $X_{1}\left(Y_{1}\right)$ and $X_{2}\left(Y_{2}\right)$ refer to backward trajectories 1 and 2, respectively. A two-step algorithm was used to produce the clusters. First, a Hartigan's $K$ mean algorithm was used to construct several clusters of backward trajectories. Those clusters were then examined visually, and selected backward trajectories were moved from one cluster to another in order to define clusters that were easier to interpret with respect to geographical and/or anthropogenic source regions. In this study, three clusters were chosen as representative of the backward trajectory clusters. The simulation was conducted using the GIS-based TrajStat software (Wang et al., 2009).

\subsubsection{Concentration-weighted trajectory (CWT) model}

A CWT model was used to construct the spatial distribution of the $\mathrm{rBC}$ sources that potentially influenced the air sampled at Lulang. For the CWT calculations, the entire geographic region covered by the 3-day backward trajectories was separated into $\sim 8100$ grid cells of $0.5^{\circ}$ latitude $\times 0.5^{\circ}$ longitude. Each grid cell was assigned a residence-time-weighted concentration obtained by the hourly averaged $\mathrm{rBC}$ concentration associated with the trajectories that crossed that grid cell (Hsu et al., 2003):

$C_{i j}=\frac{\sum_{l=1}^{M} C_{l} \tau_{i j l}}{\sum_{l=1}^{M} \tau_{i j l}}$,

where $C_{i j}$ is the average weighted concentration in the $i j$ th grid cell; $C_{l}$ is the measured $\mathrm{rBC}$ concentration on the arrival of trajectory $l ; \tau_{i j l}$ is the number of trajectory endpoints in the $i j$ th grid cell by trajectory $l$; and $M$ is the total number of trajectories. A high $C_{i j}$ value indicates that air parcels that traveled over the $i j$ th grid cell would, on average, contribute significantly to the observed high rBC loading at Lulang. 


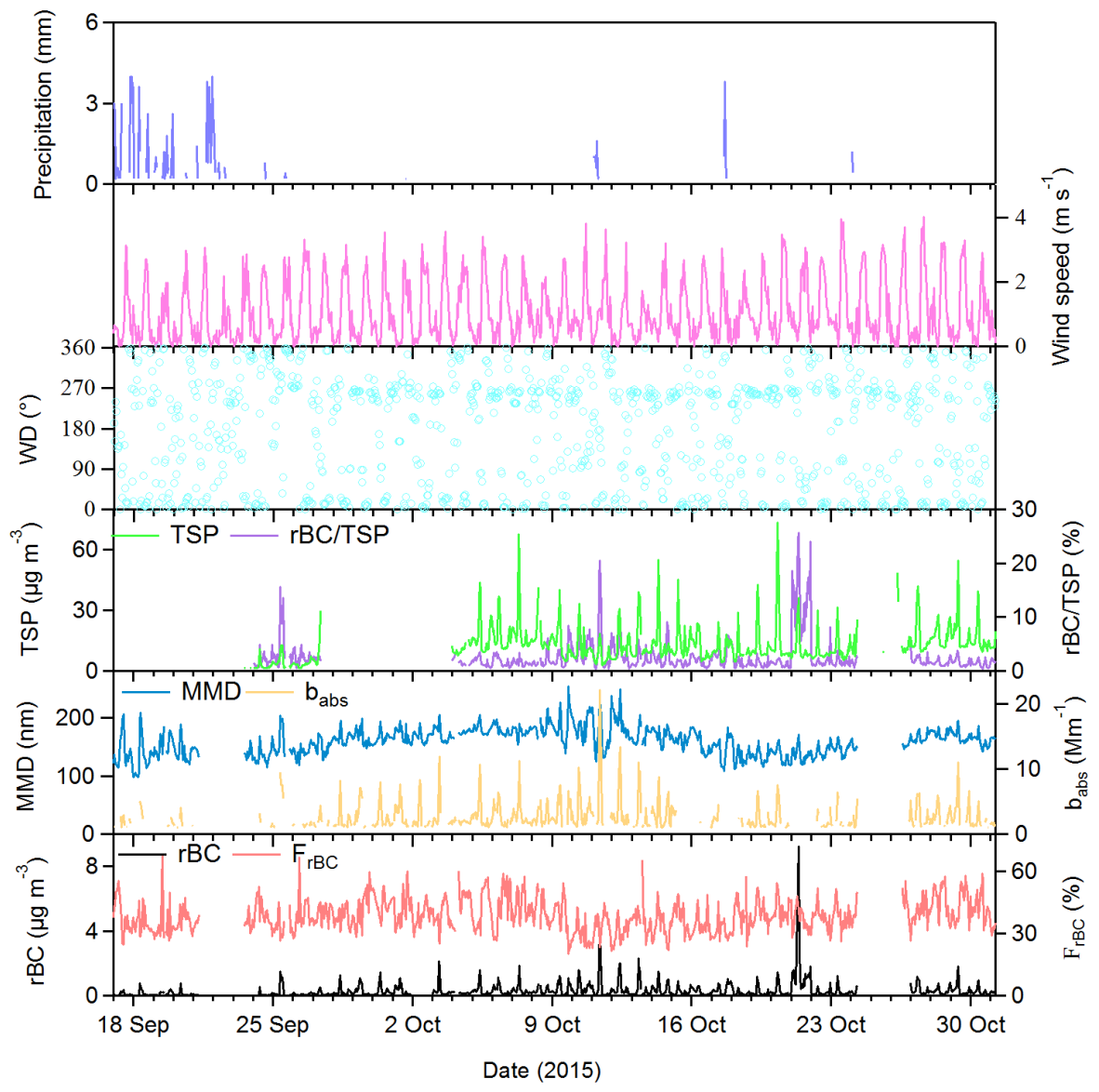

Figure 2. Time series plots of hourly averaged refractory black carbon (rBC) mass concentrations, number fraction of thickly coated $\mathrm{rBC}\left(F_{\mathrm{rBC}}\right)$, mass median diameter of $\mathrm{rBC}$ particles (MMD), total suspended particulate matter (TSP), rBC/TSP, light absorption coefficient $\left(b_{\mathrm{abs}}\right)$, wind speed, wind direction (WD), and precipitation.

\section{Results and discussion}

\subsection{Characteristics of surface $\mathrm{rBC}$}

\subsection{1 rBC loadings}

A time series plot of the hourly averaged mass concentrations of $\mathrm{rBC}$ and TSP during the entire campaign is shown in Fig. 2. The hourly average mass concentrations of $\mathrm{rBC}$ ranged from 0.002 to $9.23 \mu \mathrm{g} \mathrm{m}^{-3}$ with an arithmetic mean ( $\pm \mathrm{SD}$, standard deviation) of $0.31 \pm 0.55 \mu \mathrm{g} \mathrm{m}^{-3}$. A frequency distribution of the $\mathrm{rBC}$ mass concentrations (Fig. S5) shows that the rBC values formed a typical truncated normal distribution, with $\sim 60 \%$ of all the data below $0.2 \mu \mathrm{g} \mathrm{m}^{-3}$. However, the coefficient of variation (defined as SD/mean) for the $\mathrm{rBC}$ values was as high as $177 \%$. Furthermore, $\sim 25 \%$ of the $\mathrm{rBC}$ mass loadings were above the 75 th percentile value of $0.33 \mu \mathrm{g} \mathrm{m}^{-3}$. These results simply show that the concentrations were quite variable, and at times large loadings of $\mathrm{rBC}$ occur at Lulang.
The total average mass concentration of TSP for the study was $12.65 \pm 9.00 \mu \mathrm{g} \mathrm{m}^{-3}$, which ranged from a minimum of $1.54 \mu \mathrm{g} \mathrm{m}^{-3}$ to a maximum of $73.40 \mu \mathrm{g} \mathrm{m}^{-3}$ (Fig. 2). The rBC particles accounted for $0.4-25.6 \%$ of TSP mass and averaged $2.6 \%$. Figure S6 shows that the relationship between rBC and TSP followed two different patterns. On 21 October, the mass concentrations of $\mathrm{rBC}$ were highly correlated with the TSP mass concentrations $(r=0.97)$, but a weaker correlation $(r=0.67)$ was found for the other sampling days. Moreover, $\mathrm{rBC}$ accounted for $13.6 \%$ of TSP mass on 21 October, but the contribution was considerably smaller $(2.2 \%)$ for other sampling days. As $\mathrm{rBC}$ is produced by combustion (Bond et al., 2013), these results indicate that combustion sources contributed significantly to TSP mass on 21 October, while particles from non-combustion related sources, such as secondary aerosols and soil dust, were relatively more abundant on the other sampling days.

Figure 1 shows the spatial distribution of $\mathrm{BC}$ mass concentrations at different high-altitude locations in the Himalayas and on the TP. Information for each study from which results 
were taken is summarized in Table $\mathrm{S} 1$ in the Supplement. Although the sampling periods differed among the studies, BC generally exhibited larger loadings in the Himalayan foothills compared with those observed on the TP. On the other hand, the $\mathrm{BC}$ mass concentrations varied inversely with the altitude of the sampling sites $(r=-0.81)$ (Fig. 1). The average rBC mass concentration at Lulang was higher than what has been measured in the interior or northern TP, but it was lower than at several locations on the southeastern TP and in the Himalayan foothills (Fig. 1). The differences in BC loadings among locations can be explained by several factors. First, the concentrations are undoubtedly affected by pollutant transport from upwind regions (e.g., South Asia), and this is influenced by the complex topography of the area. For example, Zhang et al. (2015) found that on annual average $\sim 50 \%$ of the BC column burden of the Himalayas and TP was due to transport from South Asia $(\sim 33 \%$ biomass and biofuel emissions and $\sim 17 \%$ fossil fuel emissions). Second, the uncertainties caused by the inherent limitations of analytical methods themselves also help explain some of the differences in reported loadings. Indeed, previous studies have shown that the $\mathrm{BC}$ concentrations obtained from filter-based optical techniques (e.g., aethalometer) can be affected by the light-scattering artifacts (Virkkula et al., 2007), while laserinduced incandescence methods (e.g., SP2) can undersample small particles (Bond et al., 2013). Finally, there is still a lack of $\mathrm{BC}$ method intercomparisons, and there is some evidence that the differences among methods are greater for remote areas than urban ones. For instance, Wang et al. (2014) reported that a scaling factor of 2.5 was needed to adjust the eBC mass concentrations measured with an aethalometer to match SP2 measurements at a remote site on the northeastern TP, while the corresponding value at an urban site was 1.3. Moreover, filter-based EC measurements based on thermal-optical reflectance methods may be affected by the presence of carbonates (Li et al., 2017). In some areas of the TP, mineral dust particles, including carbonates, can contribute considerably to the aerosol populations due to the general lack of vegetative cover and long-range transport. Therefore, limitations such as those mentioned above make it difficult to establish scaling factors to reconcile the various $\mathrm{BC}$ measurements on the TP to a common standard, and direct comparisons of BC data obtained by different methods can be tenuous.

\subsubsection{Diurnal variations}

Figure $3 \mathrm{a}-\mathrm{c}$ show the diurnal variations of the average $\mathrm{rBC}$ mass concentrations, PBL heights, and wind speeds during the campaign. The $\mathrm{rBC}$ mass concentrations decreased slightly after midnight to reach a low value of $0.16 \mu \mathrm{g} \mathrm{m}^{-3}$ in the early morning, around 05:00 LT (local time - all time references below are given in LT); that was followed by a sharp increase at a rate of $0.35 \mu \mathrm{g} \mathrm{m}^{-3} \mathrm{~h}^{-1}$ to a maximum value of $1.21 \mu \mathrm{g} \mathrm{m}^{-3}$ around 09:00. The rBC loadings then decreased rapidly at $0.36 \mu \mathrm{g} \mathrm{m}^{-3} \mathrm{~h}^{-1}$ and reached a diurnal minimum

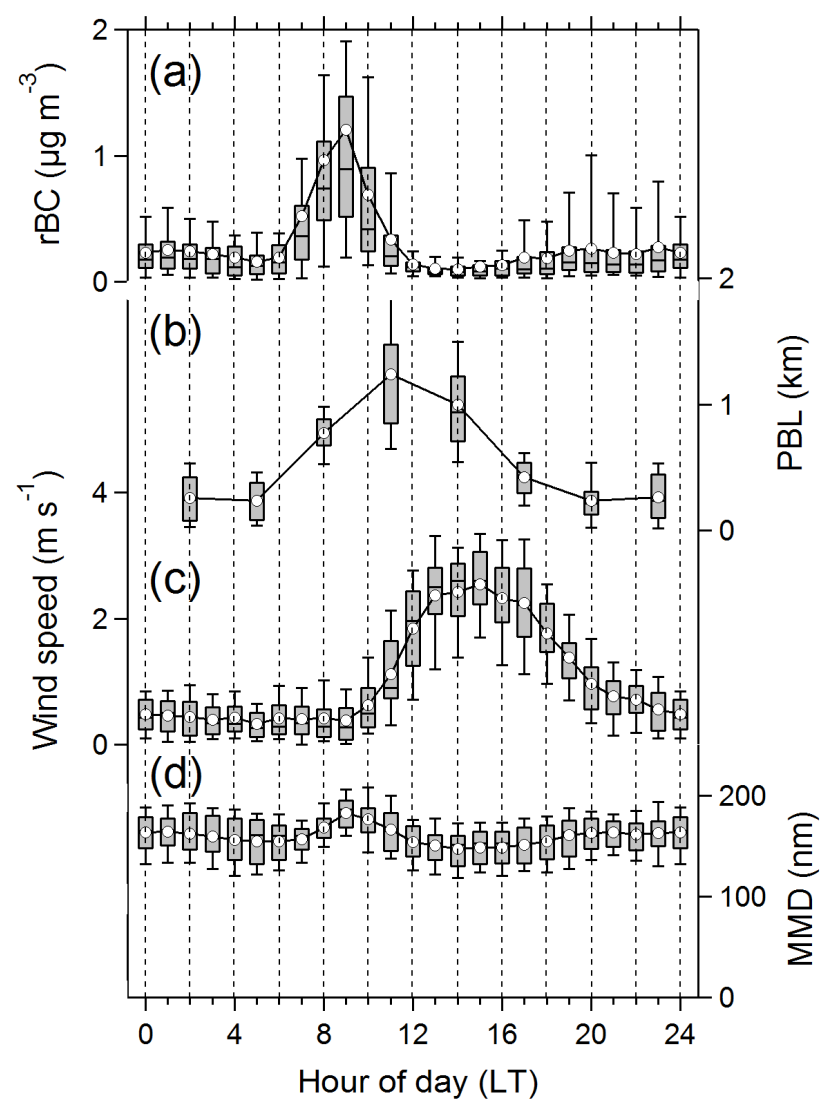

Figure 3. Diurnal variations of (a) refractory black carbon (rBC) mass concentrations, (b) planetary boundary layer (PBL) heights, (c) wind speeds, and (d) mass median diameters of the rBC particles (MMD). The lower and upper edges of the boxes denote the 25 and $75 \%$ percentiles, respectively. The short black lines and white circles inside the boxes indicate the median and mean values, and the vertical bars ("whiskers") show the 10th and 90th percentiles. LT stands for local time.

of $0.10 \mu \mathrm{g} \mathrm{m}^{-3}$ in the afternoon around 14:00. Thereafter, the $\mathrm{rBC}$ again increased gradually to a small peak of $0.26 \mu \mathrm{g} \mathrm{m}^{-3}$ at night around 20:00. After that, the concentrations were relatively stable until 01:00.

Previous studies in urban areas have often shown a morning peak in BC caused by local rush hour traffic (e.g, Cao et al., 2009; Wang et al., 2016a). In contrast, slight morning enhancements in $\mathrm{BC}$ have been found at some sites on the TP, and those were attributed to local anthropogenic activities (e.g., Wang et al., 2014; M. Wang et al., 2016). In our study, a morning peak was observed at Lulang, but the rBC loadings' enhancements were as much as 6 times the minimum values. The morning peaks were consistent with the day-to-day activities of the local residents, especially cooking, indicating that there can be some contributions of $\mathrm{rBC}$ from local sources. However, local emissions alone may not explain such a large increase in concentrations in the morning. This can be assessed indirectly by comparing the morn- 
ing peaks with the much smaller $\mathrm{rBC}$ enhancements in the evening around 19:00-20:00, which also were influenced by local cooking activities. Thus, the large morning peaks may have resulted from the combined effects of local activities and regional transport. As shown in Fig. 3a and b, the rapid morning increases in $\mathrm{rBC}$ were accompanied by deepening of the PBL, which suggests the possibility that regional transport had an important influence on rBC particles. Located to the southwest of Lulang, Bangladesh and the IGP are known to be strong sources of BC particles (Zhang et al., 2009). The PBL height is typically shallow and stable at night, and pollutants from the IGP and Bangladesh tend to be confined near the surface at that time. After sunrise, as the PBL starts to deepen, strengthening thermals lift and eventually break up the nighttime inversion. These changes in the atmosphere provide conditions that could support the transport of pollutants to the southeastern TP.

This explanation concerning the effects of transport is further supported by the analysis of true color images of haze clouds retrieved by MODIS on the Terra satellite (Fig. S7). That satellite passed over the study region at $\sim 10: 30$, and even though only several sampling days (20-23 October) were selected for inclusion in Fig. S7, most days exhibited similar patterns. The true color images reveal obvious pollution bands along the IGP and Bangladesh that piled up on the southern margin of the TP. The prevailing wind direction around the southeastern margin of the TP was southerly (Fig. S7), and therefore, the aerosols in the pollution bands were subject to transport along the valley of the Yarlung Tsangpo River to our sampling site. Indeed, this pathway has been considered a "leaking wall" for pollutant transport to the southeastern TP (Cao et al., 2010).

The decreasing trend in $\mathrm{rBC}$ loadings in the late morning at Lulang is consistent with the continued deepening of the PBL (Fig. 3b) and the strengthening winds from the northeast (see Figs. 2 and 3c). Those meteorological conditions also can explain the daily minima in the $\mathrm{rBC}$ loadings in the afternoon because they cause the dilution and dispersal of the ambient aerosols, including $\mathrm{rBC}$. The slight enhancement of $\mathrm{rBC}$ at night can be attributed to shallow PBLs and low winds in addition to increased local $\mathrm{rBC}$ anthropogenic emissions from daily activities, such as cooking and heating. It should be noted that even though the average $\mathrm{rBC}$ concentration from 08:00 to 10:00 on 21 October was $\sim 8$ times higher than the average value for other sampling days, the diurnal pattern of 21 October was similar to that seen on other days (Fig. S8a). Indeed, the rBC diurnal loading pattern did not appear to be different on this high rBC concentration day (Fig. S8b and c). Over short timescales, such as the length of our study, one can assume that the local emission sources are relatively stable. Based on the 3-day backward trajectory analysis, sudden high $\mathrm{rBC}$ loadings such as those on the morning on 21 October may be explained by the slow passage of air over Guwahati in northeastern India (Fig. S9). Large numbers of $\mathrm{rBC}$ particles likely accumulated in the air as it slowly passed over this polluted region, and it was those particles that were eventually transported to Lulang.

\subsection{Meteorological effects on $\mathrm{rBC}$ concentrations}

Wet deposition is the major mechanism by which $\mathrm{BC}$ aerosol is removed from the atmosphere (Bond et al., 2013). During the rain events at Lulang, the hourly precipitation varied from 0.2 to $4.0 \mathrm{~mm}$ (Fig. 2). The total sum of precipitation during the campaign was $104.8 \mathrm{~mm}$. Rain events occurred in $\sim 30 \%$ of the sampling period, and $\sim 70 \%$ of the rain occurred in September due to the influx of moist warm air from the Indian and Pacific oceans (Kang et al., 2002). The average mass concentration of $\mathrm{rBC}$ during rainy days $\left(0.25 \pm 0.13 \mu \mathrm{g} \mathrm{m}^{-3}\right)$ was $\sim 45 \%$ lower than on non-rainy days $\left(0.36 \pm 0.38 \mu \mathrm{g} \mathrm{m}^{-3}\right)$. Figure S10 shows the impact of daily precipitation on $\mathrm{rBC}$ loadings; that is, the $\mathrm{rBC}$ mass concentrations were negatively correlated with precipitation amount $(r=-0.51)$. In the classification scheme for daily precipitation issued by the China Meteorological Administration (GB/T 28592-2012), light, moderate, and heavy rain is defined as precipitation with ranges of 0.1-9.9, 10.0-24.9, and $25.0-49.9 \mathrm{~mm}$ within $24 \mathrm{~h}$, respectively. When the daily precipitation was less than $10 \mathrm{~mm}$, the $\mathrm{rBC}$ loadings had large fluctuations, ranging from 0.06 to $0.45 \mu \mathrm{g} \mathrm{m}^{-3}$. However, when the daily precipitation was higher than $10 \mathrm{~mm}$, the $\mathrm{rBC}$ values were $<0.14 \mu \mathrm{g} \mathrm{m}^{-3}$, suggesting that $\mathrm{rBC}$ particles are removed more efficiently by moderate or strong rain compared with light rain. A $t$ test for the $\mathrm{rBC}$ concentrations during light and strong rains showed that there was a statistically significant difference between them at a probability for chance occurrence of $p<0.01$.

Wind speed and wind direction play crucial roles in the dilution and dispersion of pollutants (Fast et al., 2007). Figure 4a shows the wind speeds and directions during the study. Overall, the prevailing surface wind directions were westerly and northerly, and these sectors combined accounted for $\sim 70 \%$ of the total wind frequencies. The average wind speed was $1.07 \pm 0.93 \mathrm{~m} \mathrm{~s}^{-1}$, and the higher wind speeds were most often associated with northerly flow. To investigate the potential for the horizontal advection of $\mathrm{rBC}$, we examined the relationships between $\mathrm{rBC}$ loadings and wind speed and wind direction using a bivariate polar plot (Fig. 4b). When the wind speed exceeded $1 \mathrm{~m} \mathrm{~s}^{-1}$, large rBC loadings were associated with airflow from the southeast. This is the compass sector that captures transport from Yarlung Tsangpo River valley, which as noted above can bring pollutants to our site from the IGP and Bangladesh (Cao et al., 2010; S. Zhao et al., 2017). High rBC mass concentrations also occurred under static conditions or low winds $\left(<1 \mathrm{~m} \mathrm{~s}^{-1}\right)$, which typically promote the accumulation of locally generated pollutants near the Earth's surface. In contrast, low levels of $\mathrm{rBC}$ were observed when the winds were from the north-northwest. This is likely because upwind regions in those directions contained few rBC sources. 


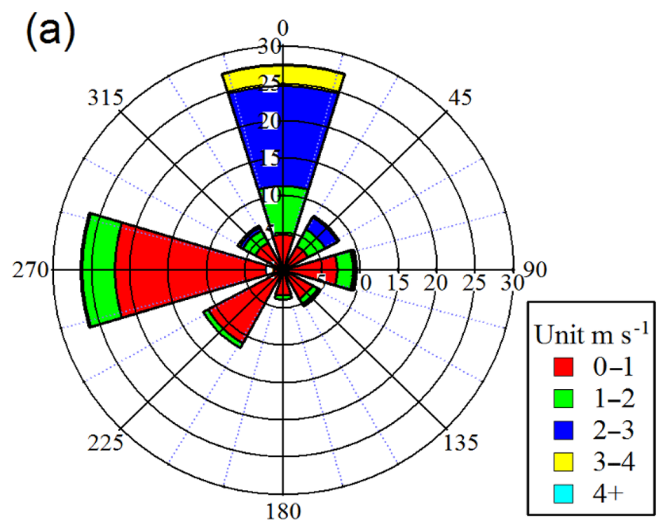

(b)

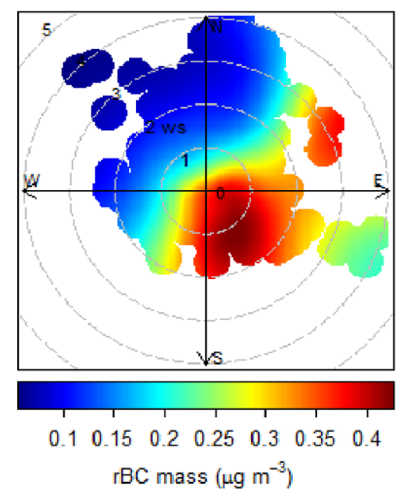

Figure 4. (a) Wind rose plot and (b) bivariate polar plot for the refractory black carbon (rBC) mass concentrations based on hourly data.

Therefore, strong winds from the north-northwest sectors would tend to dissipate the $\mathrm{rBC}$ particles.

To evaluate the surface transport of $\mathrm{rBC}$ to Lulang from the south (arbitrarily designated as positive, from outside the TP, e.g., IGP and Bangladesh) and north (negative, from the interior of the TP), surface transport intensities were calculated from Eq. (1) based on the observed rBC mass concentrations, wind speed, and wind direction at the sampling site. The estimated overall net surface transport of $\mathrm{rBC}$ was $+0.05 \pm 0.29 \mu \mathrm{g} \mathrm{s}^{-1}$, indicating greater transport of $\mathrm{rBC}$ from outside of the TP than from the interior of it. The large coefficient of variation $(580 \%)$ of the surface transport intensity reflects strong fluctuations in transport, and at least two factors likely influenced the transport processes. First, the surface fluxes were more than likely strongly affected by the prevailing winds. Figure 5 shows the variations in the hourly averaged surface transport intensity of $\mathrm{rBC}$ and the corresponding wind vectors $\left(\mathrm{m} \mathrm{s}^{-1}\right)$. In general, the $\mathrm{rBC}$ transport intensities exhibited a clear "saw-toothed" pattern, with changes in the influx (positive) and outflux (negative) patterns corresponding to shifts in wind direction (Fig. 5a). Second, differences in the emission intensities for pollutants in the upwind areas are another factor that likely affected the transport of $\mathrm{rBC}$. For example, the average influx intensity $\left(+0.18 \pm 0.27 \mu \mathrm{g} \mathrm{s}^{-1} \mathrm{~m}^{-2}\right)$ for $\mathrm{rBC}$, which includes transport from IGP and Bangladesh, was twofold stronger than the efflux intensity $\left(-0.09 \pm 0.24 \mu \mathrm{g} \mathrm{s}^{-1} \mathrm{~m}^{-2}\right)$ (Fig. 5b).

\subsection{Effects of regional transport}

Figure 6a shows the three cluster mean trajectories that were constructed from the individual 3-day backward trajectories for the campaign. For discussion purposes, we arbitrarily defined a trajectory as "polluted" if it corresponded to an rBC concentration higher than the 75th percentile value of $0.33 \mu \mathrm{g} \mathrm{m}^{-3}$; otherwise it was classified as a "clean" trajectory. The average rBC mass concentrations for the three clus-
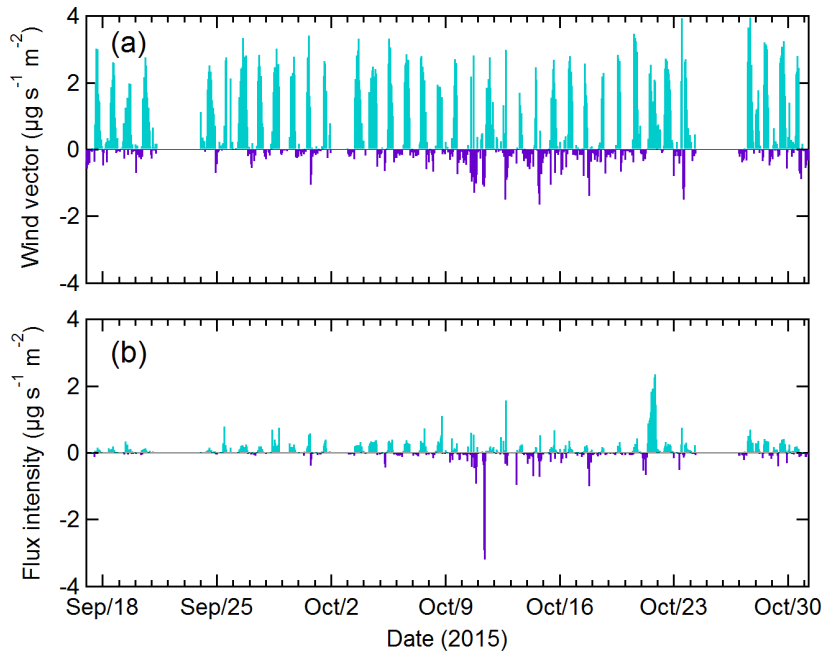

Figure 5. Time series plots of (a) wind vector $\left(=\frac{1}{n} \sum_{j=1}^{n} \mathrm{WS}_{j} \times \cos \theta_{j}\right)$ and (b) surface transport intensity for refractory black carbon (rBC) based on the hourly averaged data at the Lulang site. Positive values indicate the transport direction of $\mathrm{rBC}$ from south to north (i.e., from the Indo-Gangetic Plain and Bangladesh to Lulang) and the negative values represent the transport direction of $\mathrm{rBC}$ from north to south (i.e., from the interior of the Tibetan Plateau) to Lulang.

ters and the polluted trajectories are summarized in Table 1. The air masses grouped into Cluster no. 1 originated from north India and passed through central Nepal and the southern TP before arriving at Lulang. The average rBC mass concentration for Cluster no. 1 was $0.37 \pm 0.71 \mu \mathrm{g} \mathrm{m}^{-3}$. Of all 887 backward trajectories included in the analysis, $\sim 47 \%$ were allocated to Cluster no. 1 , and $\sim 29 \%$ of those were considered polluted. The average $\mathrm{rBC}$ mass concentration for these polluted trajectories was $0.95 \mu \mathrm{g} \mathrm{m}^{-3}$. The air masses grouped into Cluster no. 1 were responsible for many of the 

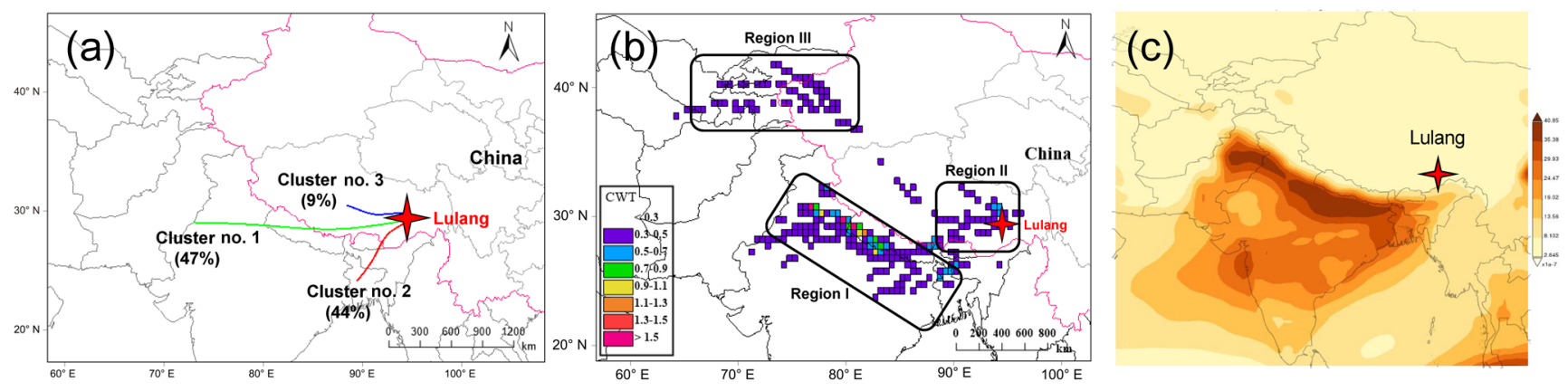

Figure 6. Maps of (a) the mean trajectory clusters, (b) the concentration-weighted trajectories (CWT, $\mu \mathrm{g} \mathrm{m}^{-3}$ ) for refractory black carbon mass concentrations, and (c) the reconstructed black carbon column mass densities $\left(\mathrm{kg} \mathrm{m}^{-2}\right)$ during the campaign.

Table 1. Trajectory clusters and mean refractory black carbon (rBC) concentration for each cluster.

\begin{tabular}{lrcclrrrr}
\hline \multirow{2}{*}{ Cluster } & \multicolumn{3}{c}{ All trajectories } & & \multicolumn{3}{c}{ Polluted rBC trajectories } \\
\cline { 2 - 3 } \cline { 7 - 8 } & Number & Mean & SD $^{\mathrm{a}}$ & & Number & Mean & SD $^{\mathrm{b}}$ \\
\hline no. 1 & 421 & 0.37 & 0.71 & & 120 & 0.95 & 1.14 \\
no. 2 & 390 & 0.24 & 0.36 & & 81 & 0.75 & 0.52 \\
no. 3 & 76 & 0.32 & 0.31 & & 23 & 0.72 & 0.29 \\
\hline All & 887 & 0.31 & 0.55 & & 224 & 0.86 & 0.90 \\
\hline
\end{tabular}

a Trajectories associated with $\mathrm{rBC}$ concentration $>0.33 \mu \mathrm{g} \mathrm{m}^{-3}$ (75th percentile value).

b SD represents standard deviation.

high $\mathrm{rBC}$ loadings at the receptor site. The air masses associated with Cluster no. 2 originated from central Bangladesh and then moved across northeastern India and to the southeast of Tibet before arriving at Lulang. The average $\mathrm{rBC}$ mass concentration for Cluster no. 2 was $0.24 \pm 0.36 \mu \mathrm{g} \mathrm{m}^{-3}$. The percentage of the trajectories assigned to this cluster was $\sim 44 \%$, and $\sim 20 \%$ of those were regarded as polluted. The average mass concentration of the polluted trajectories in Cluster no. 2 was $0.75 \mu \mathrm{g} \mathrm{m}^{-3}$. The air masses in Cluster no. 3 originated over central Tibet, and the average $\mathrm{rBC}$ mass concentration for this cluster $\left(0.32 \pm 0.31 \mu \mathrm{g} \mathrm{m}^{-3}\right)$ was similar to that for Cluster no. 1. Although the percent contribution from this cluster was $\sim 9 \%$ of all trajectories, $\sim 30 \%$ of the trajectories in Cluster no. 3 were classified as polluted, and they had a mean value of $0.72 \mu \mathrm{g} \mathrm{m}^{-3}$. This implies some contributions of $\mathrm{rBC}$ from internal Tibetan sources.

A CWT model was used to better identify the locations of the potential source areas that provided $\mathrm{rBC}$ to Lulang, and a map of the CWT results for the campaign is shown in Fig. $6 \mathrm{~b}$. There were three main source regions contributing to the $\mathrm{rBC}$ pollution at Lulang. Region I was mainly composed of areas along the southern border of the Himalayan foothills, IGP, and north Bangladesh. This region had the highest CWT values, indicating that this area had the greatest probability for causing the high $\mathrm{rBC}$ loadings at Lulang, and it is also worth noting that there are high $\mathrm{BC}$ column mass densities in this area (Fig. 6c). In contrast, moderate CWT values were found for areas to the west of Lulang and adjoining regions (Region II), suggesting local anthropogenic activities in the interior of the TP also contributed to the rBC loadings at Lulang. Several cities, including Lhasa, Gongbu Jiang, and Linzhi, are located $\sim 60-350 \mathrm{~km}$ to the west of Lulang, and these are possible sources of anthropogenic materials. Although the population is sparse in the areas surrounding Lulang, biofuels, especially wood and yak dung, are the main energy sources for local residents (Ping et al., 2011). Domestic heating and cooking using these fuels typically produces large quantities of rBC particles, and therefore, these sources probably affected the sampling site. Region II evidently had lesser effects on the rBC loadings compared with the Region I because the CWT values for Region II were lower. It is worth noting that even though Region III extended to the southwest of Sinkiang Province, China, and several central Asian countries that emit substantial quantities of $\mathrm{BC}$, this region had only minor impacts on the rBC because the air masses from Region III composed less than $\sim 1 \%$ of the total trajectories.

\subsection{Microphysical properties}

\subsubsection{Size distributions of $\mathrm{rBC}$}

Figure $\mathrm{S} 1$ shows that $\mathrm{rBC}$ core size distribution was well represented by a mono-modal log-normal fit. This is consistent with the size distributions constructed from previous SP2based observations made across the globe, including urban, rural, and remote areas (e.g., Schwarz et al., 2008; Liu et al., 2010; McMeeking et al., 2011; Huang et al., 2012; Wang et al., 2014). As shown in Fig. 2, the hourly averaged mass median diameters (MMDs - the VED at the peak of the mass distribution) varied broadly from 98 to $255 \mathrm{~nm}$ during the study, and the average was $160 \pm 23 \mathrm{~nm}$. The rBC MMDs exhibited diurnal patterns similar to the $\mathrm{rBC}$ mass concentrations; that is, they peaked in the morning around 09:00 $(\sim 183 \mathrm{~nm})$, fell to a minimum in the afternoon around 14:00 $(\sim 147 \mathrm{~nm})$, then rose again in the evening, and finally stabilized at night $(\sim 163 \mathrm{~nm})$ (Fig. 3d). 
Although size-segregated filter-based measurements made with cascade impactors provide information on the aerodynamic diameters of $\mathrm{BC}$ particles, they measure both the $\mathrm{BC}$ cores and any coatings on the particles. In contrast, the SP2 measures the rBC core size alone. Consequently, we only compared our results with SP2 observations made in previous studies. Because of the different $\mathrm{rBC}$ densities assumed in the various studies, we normalized them to the same density of $1.8 \mathrm{~g} \mathrm{~cm}^{-3}$ to facilitate direct comparisons. The average $\mathrm{rBC} \mathrm{MMD}$ at Lulang fell into the lower range reported in previous SP2 studies ( 155-240 nm; Huang et al., 2012, and references therein), and it was lower than some results reported for remote areas, such as $181 \mathrm{~nm}$ at Qinghai Lake, northeastern TP (Wang et al., 2014), $194 \mathrm{~nm}$ at the Pallas Global Atmosphere Watch station, Finnish Arctic (Raatikainen et al., 2015), and 220-240 $\mathrm{nm}$ at the high alpine research station Jungfraujoch, Switzerland (Liu et al., 2010).

The variations in $\mathrm{rBC}$ MMDs among sites were likely related to the following factors. First, the various emission sources produce rBC particles of different sizes. For example, Sahu et al. (2012) observed larger average rBC MMDs in biomass burning plumes $(193 \mathrm{~nm})$ compared with fossil fuel plumes $(175 \mathrm{~nm})$. Wang et al. (2016b) reported a higher average rBC MMD for coal burning $(215 \mathrm{~nm})$ compared with particles from a traffic source $(189 \mathrm{~nm})$. Second, transport histories matter because aging of the particles can affect the size distributions of $\mathrm{rBC}$. Take the cluster analysis as an example: the average $\mathrm{rBC}$ MMD was the largest $(184 \pm 17 \mathrm{~nm})$ when the polluted air masses originated from central Bangladesh (Cluster no. 2). In contrast, smaller rBC MMDs were found when the polluted air masses came from north India (Cluster no. $1,173 \pm 26 \mathrm{~nm}$ ) or the central TP (Cluster no. 3, $177 \pm 19 \mathrm{~nm}$ ). These air masses originated from different sources regions, and they may have had different $\mathrm{rBC}$ sizes initially; but the $\mathrm{rBC}$ core sizes also may have changed during transport through coagulation. It should be noted that a $t$ test for the rBC MMDs from different clusters showed that there was a statistically significant difference between Cluster no. 1 and no. $2(p<0.01)$ but no significant difference between Cluster no. 2 and no. 3 ( $p=0.09$ ).

Finally, wet deposition may exert a significant effect on the $\mathrm{rBC}$ size distributions. This can be seen in Fig. 7, which presents a comparison of the frequency distributions of $\mathrm{rBC}$ MMDs during rainy and non-rainy sampling days. The rBC MMDs varied from 112 to $255 \mathrm{~nm}$ with an average of $164 \pm 21 \mathrm{~nm}$ for the non-rainy days, and about $50 \%$ of the MMDs were within the range of $150-175 \mathrm{~nm}$. In contrast, the rBC MMDs for rainy days shifted toward smaller sizes, varying from 98 to $230 \mathrm{~nm}$ and averaging $145 \pm 25 \mathrm{~nm}$. About $40 \%$ of the MMDs for the rainy day samples were in the range of $125-145 \mathrm{~nm}$. We note that the sizes of the particles on rainy days may be representative of local sources because rain also fell over South Asia, and therefore, there was little long-range transport of $\mathrm{rBC}$ to Lulang under those conditions. Compared with non-rainy days, the smaller rBC

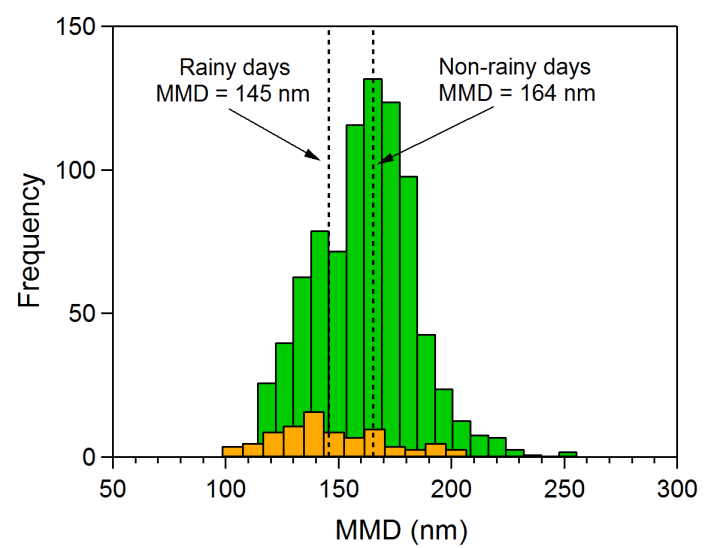

Figure 7. Frequency distributions of mass median diameters (MMDs) for rainy and non-rainy sampling days. The vertical dashed lines denote the average MMDs for those two types of days.

on rainy days can be explained by the absence of long-range transport and by the preferential wet scavenging of larger rBC cores (Taylor et al., 2014).

\subsubsection{Evolution of $\mathrm{rBC}$ mixing state}

The average $F_{\mathrm{rBC}}$ was $39 \pm 8 \%$ (range of $20-68 \%$, Fig. 2) during the entire campaign, which is lower than what has been reported for Qinghai Lake (59\%, Wang et al., 2015a), where a similar method was used to measure the internal mixing of rBC. Air masses in Cluster no. 2 showed the highest internal mixing of rBC particles (40\%), followed by Cluster no. 1 (38\%) and Cluster no. $3(34 \%)$. The low percentages of internal mixing for $\mathrm{rBC}$ particles in these three clusters indicate a relatively low level of particle aging. This implies that freshly emitted local rBC particles were part of the sample population. Figure 8a shows that the diurnal cycle of $F_{\mathrm{rBC}}$ at Lulang typically exhibited "two peaks and two valleys". The percentage of internally mixed $\mathrm{rBC}$ reached a peak value of $45 \%$ in the morning around 07:00-08:00, followed by a decreasing trend to a low value of $35 \%$ around 10:00. The internally mixed $\mathrm{rBC}$ then increased to a secondary peak value of $44 \%$ in the afternoon around 14:00 and again slowly decreased to a minimum of $33 \%$ around 01:00.

The variations in percentages of internally mixed $\mathrm{rBC}$ in the morning further provide evidence for the combined effects of local activities and regional transport on the $\mathrm{rBC}$ aerosol. That is, the enhancement of internally mixed $\mathrm{rBC}$ around 07:00-08:00 can be attributed to $\mathrm{rBC}$ aging, which indicates impacts from regional transport. The decreasing trend of $F_{\mathrm{rBC}}$ around 09:00-10:00 was likely due to an increase in fresh $\mathrm{rBC}$ particles emitted by local anthropogenic activities, even though the local population was small. As the day progressed from 10:00 to 19:00, $F_{\mathrm{rBC}}$ varied with $\mathrm{O}_{3}$ mixing ratios (Fig. 8a), suggesting a possible effect of oxidants on the internal mixing of rBC. It can be seen in Fig. $8 \mathrm{~b}$ that $F_{\mathrm{rBC}}$ was 

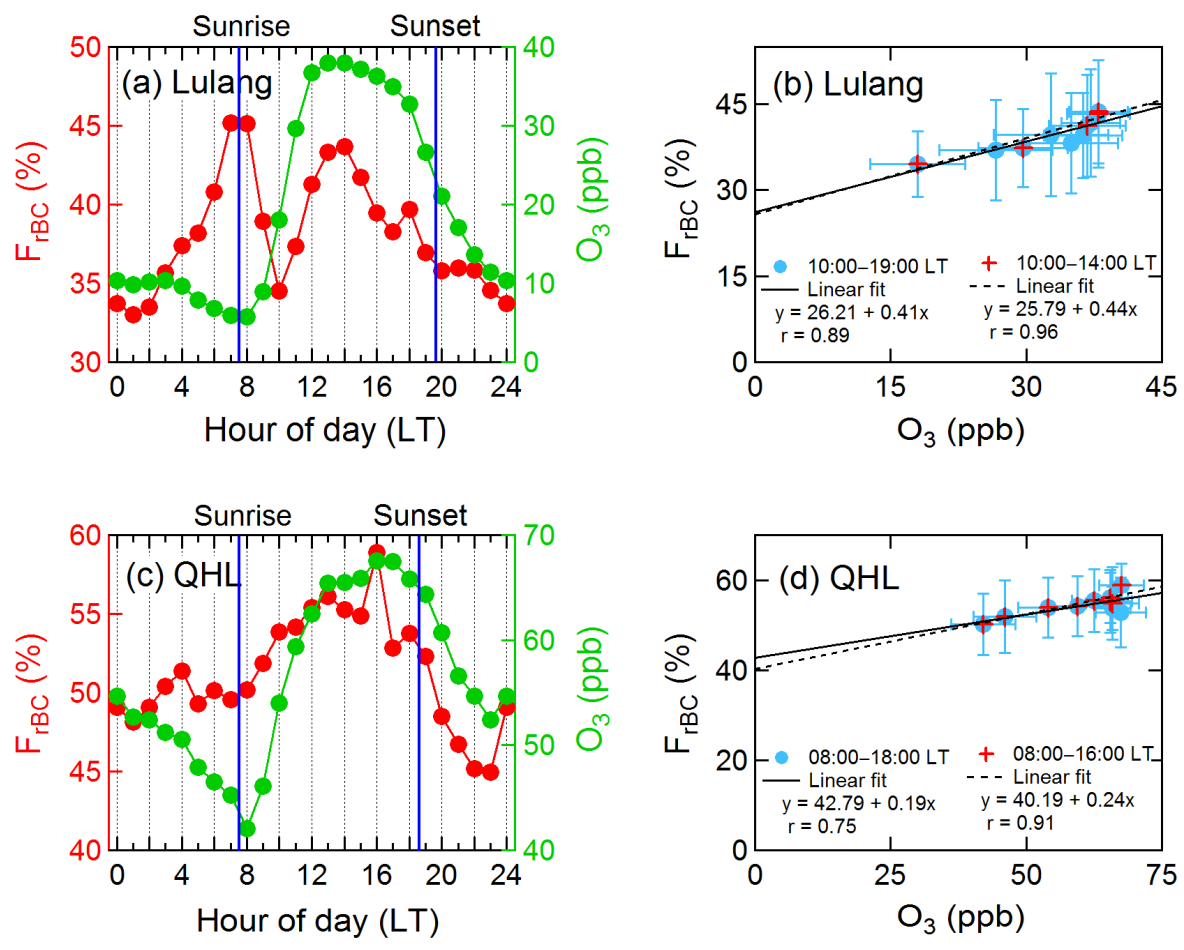

Figure 8. (a, c) Diurnal variations of the hourly averaged number fraction of thickly coated refractory black carbon particles $\left(F_{\mathrm{rBC}}\right)$ and $\mathrm{O}_{3}$ mixing ratios at Lulang and Qinghai Lake $(\mathrm{QHL})$ and $(\mathbf{b}, \mathbf{d})$ linear regressions between $F_{\mathrm{rBC}}$ and $\mathrm{O}_{3}$ at these two sites.

positively correlated with the $\mathrm{O}_{3}$ mixing ratio $(r=0.89)$, indicating that more internal mixing for $\mathrm{rBC}$ particles occurred under more oxidizing conditions. Further, the observed increasing trend for internally mixed $\mathrm{rBC}$ from 10:00 to 14:00 can be explained by the mixing of $\mathrm{rBC}$ particles with secondary aerosols (e.g., non-refractory inorganic and organic compounds) that resulted from enhanced photochemical oxidation due to the daily cycle in insolation.

To further investigate the effects of photochemical oxidation on the rBC mixing state, we compared the diurnal variations of internal mixing for $\mathrm{rBC}$ particles at Lulang with observations made at Qinghai Lake, a site in the northeastern TP, where studies were conducted in October 2011 (Fig. 8c). The $\mathrm{rBC}$ and $\mathrm{O}_{3}$ at Qinghai Lake were measured with the same type of SP2 as in this study and an ultraviolet photometer, respectively. Detailed descriptions of the Qinghai Lake study may be found in Wang et al. (2014, 2015b). As shown in Fig. 8c, only one $F_{\mathrm{rBC}}$ peak was observed at Qinghai Lake in the afternoon between 12:00 and 17:00, which was different from what we observed at Lulang. This difference can be explained by the fact that $\mathrm{rBC}$ in the early morning at Qinghai Lake was not affected by long-range transport, owing to the topography of the region (Wang et al., 2014). Even so, similar to Lulang, the $F_{\mathrm{rBC}}$ during the daytime (08:0018:00) at Qinghai Lake was positively correlated with the $\mathrm{O}_{3}$ mixing ratio $(r=0.75$, Fig. $8 d)$, and these results are additional evidence that photochemical oxidation is involved in the formation of the coatings on $\mathrm{rBC}$ particles from the TP. Moreover, the variations in $F_{\mathrm{rBC}}$ during the daytime at $\mathrm{Lu}-$ lang also co-varied with the PBL height, indicating that aged rBC particles may have been transported from aloft to the surface.

\section{5 rBC optical properties}

The average $b_{\text {abs }}$ at $\lambda=870 \mathrm{~nm}$ for the campaign was $2.9 \pm 2.4 \mathrm{Mm}^{-1}$ (Fig. 2). Some organic materials (also called brown carbon) can cause significant light absorption, but those effects are mainly at short wavelengths (e.g., $\lambda=370 \mathrm{~nm}$ ), and they have nearly no absorption in the near-infrared spectral region (e.g., $\lambda=870 \mathrm{~nm}$ ) (Laskin et al., 2015). Consequently, it is reasonable to calculate the mass absorption cross section of $\mathrm{rBC}\left(\mathrm{MAC}_{\mathrm{rBC}}, \mathrm{m}^{2} \mathrm{~g}^{-1}\right)$, which describes the degree of light absorption per unit mass of $\mathrm{rBC}$, by dividing the $b_{\mathrm{abs}}$ measured with the PAX 870 by the mass concentration of $\mathrm{rBC}$ detected with the SP2 $\left(\mathrm{MAC}_{\mathrm{rBC}}=b_{\mathrm{abs}} / \mathrm{rBC}\right)$. Figure 9 shows that the $\mathrm{MAC}_{\mathrm{rBC}}$ frequency distributions were mono-modal log-normal for all samples from the campaign and for the data stratified by the three trajectory clusters. The peak in the frequency $\mathrm{MAC}_{\mathrm{rBC}}$ distribution for the entire campaign was $7.6 \mathrm{~m}^{2} \mathrm{~g}^{-1}$, and there were slightly higher values for Cluster no. 1 $\left(8.0 \mathrm{~m}^{2} \mathrm{~g}^{-1}\right)$ and Cluster no. $2\left(7.8 \mathrm{~m}^{2} \mathrm{~g}^{-1}\right)$ compared with Cluster no. $3\left(7.5 \mathrm{~m}^{2} \mathrm{~g}^{-1}\right)$. 


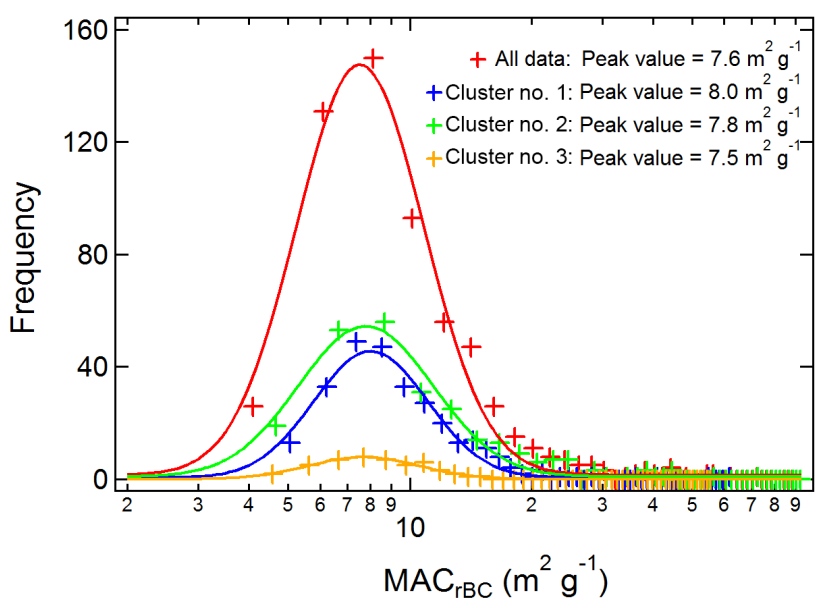

Figure 9. Frequency distributions of the mass absorption cross sections of refractory black carbon $\left(\mathrm{MAC}_{\mathrm{rBC}}\right)$ for the campaign and for air masses defined by trajectory cluster.

Absorption enhancements for the $\mathrm{rBC}\left(E_{\mathrm{abs}}=\mathrm{MAC}_{\mathrm{rBC}} /\right.$ $\mathrm{MAC}_{\mathrm{rBC}}$,uncoated) were calculated to further characterize the rBC particles' optical properties. As the SP2 only determines the $\mathrm{rBC}$ core size, the hourly averaged MMDs for the $\mathrm{rBC}$ were input into the Mie model to calculate the $\mathrm{MAC}_{\mathrm{rBC}}$ of uncoated $\mathrm{rBC}$ particles $\left(\mathrm{MAC}_{\mathrm{rBC}}\right.$,uncoated $)$, assuming that the uncoated $\mathrm{rBC}$ particles were spherical and homogeneous. A more detailed description of the Mie algorithms may be found in Bohren and Huffman (2008). For these calculations, the refractive index of $1.85-0.71 i$ at $\lambda=550 \mathrm{~nm}$ suggested by Bond and Bergstrom (2006) was first used in the Mie model to estimate the $\mathrm{MAC}_{\mathrm{rBC}}$,uncoated. Those values were then converted to the $\mathrm{MAC}_{\mathrm{rBC}}$,uncoated at $\lambda=870 \mathrm{~nm}$ based on an rBC absorption Ångström exponent of 1.0 (Moosmüller et al., 2011). Finally, the average rBC absorption enhancement was calculated by comparing the $\mathrm{MAC}_{\mathrm{rBC}}$ at $\lambda=870 \mathrm{~nm}$ for $\mathrm{rBC}$ with and without coatings. As shown in Fig. 9, there were several anomalously large $\mathrm{MAC}_{\mathrm{rBC}}$ values that were likely caused by the uncertainties associated with extremely low $b_{\text {abs }}$ and $\mathrm{rBC}$ mass concentrations. To avoid spurious results such as these, only $\mathrm{MAC}_{\mathrm{rBC}}$ values in the lower 90th percentile of all data were used to calculate the $E_{\text {abs. }}$. As shown in Fig. S11, the $E_{\text {abs }}$ values generally followed a mono-modal log-normal distribution with a peak value of 1.9 , which is an indication that the light absorption of coated $\mathrm{rBC}$ particles was significantly greater than that of uncoated ones.

To investigate the potential impacts of $\mathrm{rBC}$ size and mixing state on light absorption, the $E_{\text {abs }}$ values were plotted against the $F_{\mathrm{rBC}}$ values and MMDs (Fig. 10). As shown in Fig. 10a, the $E_{\text {abs }}$ was strongly positive correlated with the $F_{\mathrm{rBC}}(r=0.96)$, and this supports our conclusion that there was an enhancement of light absorption by internally mixed - that is, coated $-\mathrm{rBC}$ particles. The slope of the

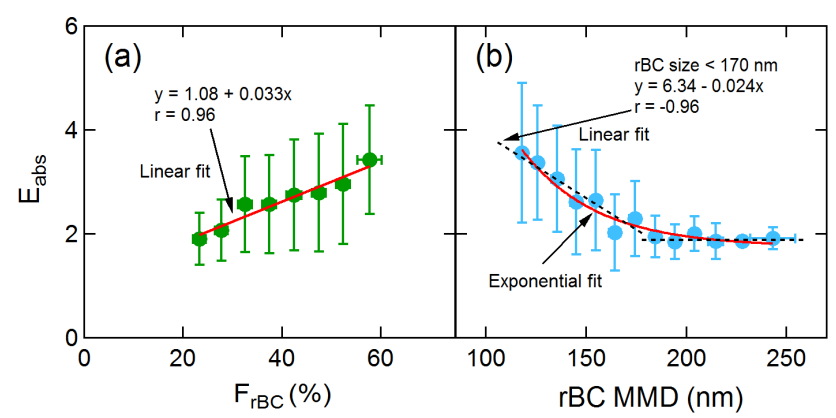

Figure 10. Absorption enhancement ( $\left.E_{\mathrm{abs}}\right)$ versus (a) the number fraction of thickly coated refractory black carbon $\left(F_{\mathrm{rBC}}\right)$ and $(\mathbf{b})$ the mass median diameter (MMD) of $\mathrm{rBC}$ during the campaign. The error bars correspond to the standard deviations of $E_{\mathrm{abs}}, F_{\mathrm{rBC}}$, and MMD.

regression line was $0.03 \%^{-1}$, which may be considered a rough estimate of the effects of the coatings on light absorption. This means that if the fraction of thickly coated $\mathrm{rBC}$ particles increased by $1 \%$, the rBC particles would absorb $3 \%$ more light. If the results of the linear regression shown in Fig. 10a are extrapolated to a condition in which $\mathrm{rBC}$ is completely uncoated (that is, $F_{\mathrm{rBC}}$ or $x=0 \%$ ), the $E_{\mathrm{abs}}$ would be 1.1, which is close to the theoretical value of 1.0 for uncoated $\mathrm{rBC}$. At the other extreme, if all $\mathrm{rBC}$ particles were internally mixed ( $F_{\mathrm{rBC}}$ or $\left.x=100 \%\right)$, the $E_{\text {abs }}$ would be as high as 4.4, which appears physically implausible. This result is confined to a narrow range of conditions, however, that is, small $\mathrm{rBC}$ core diameters with the thick coatings (Bond et al., 2006). Moreover, it is noteworthy that several studies have shown nonlinear relationships between $E_{\text {abs }}$ and the internal mixing of rBC (e.g., Zhang et al., 2016; Liu et al., 2015). In those cases, the $E_{\mathrm{abs}}$ tended to be stable over a large range of coating thicknesses. If that were the case in our study, the $E_{\text {abs }}$ would be lower than the calculated value of 4.4.

As shown in Fig. 10b, the $E_{\text {abs }}$ was nonlinearly related to the MMDs of the rBC. When $\mathrm{rBC} M M D<170 \mathrm{~nm}$, the $E_{\text {abs }}$ varied inversely with $\mathrm{rBC}$ core size, indicating that smaller $\mathrm{rBC}$ particles potentially have a stronger ability to amplify light absorption than large ones. This can be explained by the greater tendency of small $\mathrm{rBC}$ particles to form coatings than the large ones, which is due to the wellknown relationship between particle surface area and volume (see the positive correlation between $F_{\mathrm{rBC}}$ and MMDs in Fig. S12). The variations in $E_{\text {abs }}$ were relatively constant for $\mathrm{rBC}$ MMD $>170 \mathrm{~nm}$. When coatings form by condensation, a 1 diameter $^{-1}$ dependence would apply to the condensation rate. Thus, larger $\mathrm{rBC}$ cores have a smaller degree of internal mixing and weaker absorption amplification than smaller cores on the one hand, but on the other hand, larger $\mathrm{rBC}$ core size also would decrease the $\mathrm{MAC}_{\mathrm{rBC}}$, uncoated according to the Mie model (see the relationship between $\mathrm{MAC}_{\mathrm{rBC}}$,uncoated and MMD in Fig. S12). Eventually, the decrease in light ab- 
sorbing ability for the measured ambient $\mathrm{rBC}$ (that is, the $\mathrm{MAC}_{\mathrm{rBC}}$ ) and for the assumed uncoated $\mathrm{rBC}$ particles (that is, $\mathrm{MAC}_{\mathrm{rBC}}$,uncoated) would cancel out, causing a constant value for $E_{\text {abs. }}$. Indeed, Bond et al. (2006) reported that the amplification was nearly constant for $\mathrm{rBC}$ cores $>\sim 150 \mathrm{~nm}$.

\section{Conclusions}

The mass concentrations, size distributions, mixing state, and optical properties of $\mathrm{rBC}$ aerosol were studied at Lulang on the southeastern TP, China. The mass concentration of $\mathrm{rBC}$, averaged over the entire campaign, was $0.31 \pm 0.55 \mu \mathrm{g} \mathrm{m}^{-3}$, and the rBC particles accounted for $2.6 \%$ of TSP mass. A clear diurnal pattern in $\mathrm{rBC}$ mass concentrations was observed: high values occurred in the early morning due to the combined effects of local anthropogenic activities and regional transport, while low values in the afternoon were ascribed to the dispersion of the $\mathrm{rBC}$ due to deepening of the PBL and higher wind speeds. The relationship observed between rainfall and $\mathrm{rBC}$ indicated that $\mathrm{rBC}$ particles were more efficiently removed by moderate and heavy precipitation $(>10 \mathrm{~mm})$ than by light rain. A bivariate polar plot showed that high $\mathrm{rBC}$ loadings were associated with strong winds from the southeast or static wind conditions. The estimated overall net surface transport intensity of $\mathrm{rBC}$ was $+0.05 \pm 0.29 \mu \mathrm{g} \mathrm{s}^{-1} \mathrm{~m}^{-2}$. Those calculations showed that more $\mathrm{rBC}$ was brought to the site from outside the TP than from the interior of the TP. Moreover, air mass trajectory clusters and a concentration-weighted trajectory model indicated that sources in north India were the most important influences on rBC at Lulang, but local contributions were not negligible.

The rBC VEDs showed approximately mono-modal lognormal distributions. The hourly average rBC MMD was $160 \pm 23 \mathrm{~nm}$, and the MMDs varied among air parcels. The MMDs shifted toward smaller sizes $(145 \mathrm{~nm})$ on rainy days compared with non-rainy days $(164 \mathrm{~nm})$. The average $F_{\mathrm{rBC}}$ for the study was $39 \pm 8 \%$, suggesting uncoated or thinly coated rBC particles composed the bulk of the rBC population. Two peaks in $F_{\mathrm{rBC}}$ were observed: one was in the morning, which was attributed to atmospheric aging processes; the other was in the afternoon, which was explained by enhancements caused by photochemical oxidation and the mixing aged $\mathrm{rBC}$ particles from aloft into the surface. A strong correlation between $F_{\mathrm{rBC}}$ and $\mathrm{O}_{3}$ was found during the daytime at Lulang (10:00-19:00), indicating that the photochemical oxidation played an important role in the internal mixing of rBC with other materials. A similar relationship was found for samples from near Qinghai Lake in the northeastern TP.

The total average $b_{\text {abs }}($ at $\lambda=870 \mathrm{~nm}$ ) for the study was $2.9 \pm 2.4 \mathrm{Mm}^{-1}$. The $\mathrm{MAC}_{\mathrm{rBC}}$ values showed a mono-modal log-normal distribution with a peak value of $7.6 \mathrm{~m}^{2} \mathrm{~g}^{-1}$. Slightly higher $\mathrm{MAC}_{\mathrm{rBC}}$ values were found for air masses from north India $\left(8.0 \mathrm{~m}^{2} \mathrm{~g}^{-1}\right)$ and central Bangladesh $\left(7.8 \mathrm{~m}^{2} \mathrm{~g}^{-1}\right)$ compared with air transported from central Tibet $\left(7.5 \mathrm{~m}^{2} \mathrm{~g}^{-1}\right)$. By dividing the observed $\mathrm{MAC}_{\mathrm{rBC}}$ measured with the SP2 and $\mathrm{PAX}_{870}$ by the $\mathrm{MAC}_{\mathrm{rBC}}$, uncoated calculated from the Mie model, the average $E_{\text {abs }}$ was estimated to be 1.9. This suggests that the light absorption by coated rBC particles was significantly amplified compared with uncoated ones. Furthermore, the $E_{\text {abs }}$ was positively correlated with $F_{\mathrm{rBC}}$, indicating an enhancement of light absorption by internally mixed $\mathrm{rBC}$ particles. The $E_{\mathrm{abs}}$ showed a negative correlation with the $\mathrm{rBC}$ MMDs for the particle cores $<170 \mathrm{~nm}$, but it was nearly constant for larger $\mathrm{rBC}$ cores. We should note that the sources, transport, and radiative effects of the $\mathrm{rBC}$ as well as atmospheric conditions likely vary in complex ways with season, and therefore the results from our study (in autumn) are not necessarily representative of other times of the year. Indeed, additional studies need to be conducted to determine how the $\mathrm{rBC}$ aerosol at our site and others changes with season.

Data availability. All data described in this study are available upon request from the corresponding authors.

\section{The Supplement related to this article is available online at https://doi.org/10.5194/acp-18-4639-2018-supplement.}

Competing interests. The authors declare that they have no conflict of interest.

Special issue statement. This article is part of the special issue "Atmospheric pollution in the Himalayan foothills: The SusKat-ABC international air pollution measurement campaign". It is not associated with a conference.

Acknowledgements. This work was supported by the National Natural Science Foundation of China (41230641, 41503118, 41625015, and 41661144020). The authors are grateful to the Southeast Tibet Integrated Observation and Research Station for the Alpine Environment, Chinese Academy of Sciences, for their assistance with field sampling.

Edited by: Ernest Weingartner

Reviewed by: four anonymous referees 


\section{References}

Babu, S. S., Chaubey, J. P., Moorthy, K. K., Gogoi, M. M., Kompalli, S. K., Sreekanth, V., Bagare, S. P., Bhatt, B. C., Gaur, V. K., Prabhu, T. P., and Singh, N. S.: High altitude (similar to $4520 \mathrm{~m}$ amsl) measurements of black carbon aerosols over western trans-Himalayas: Seasonal heterogeneity and source apportionment, J. Geophys. Res., 116, D24201, https://doi.org/10.1029/2011JD016722, 2011.

Bohren, C. F. and Huffman, D. R.: Absorption and scattering of light by small particles, John Wiley \& Sons, New York, 2008.

Bond, T. C. and Bergstrom, R. W.: Light absorption by carbonaceous particles: an investigative review, Aerosol Sci. Tech., 40, 27-67, https://doi.org/10.1080/02786820500421521, 2006.

Bond, T. C., Habib, G., and Bergstrom, R. W.: Limitations in the enhancement of visible light absorption due to mixing state, J. Geophys. Res., 111, D20211, https://doi.org/10.1029/2006JD007315, 2006.

Bond, T. C., Doherty, S. J., Fahey, D. W., Forster, P. M., Berntsen, T., DeAngelo, B. J., Flanner, M. G., Ghan, S., Karcher, B., Koch, D., Kinne, S., Kondo, Y., Quinn, P. K., Sarofim, M. C., Schultz, M. G., Schulz, M., Venkataraman, C., Zhang, H., Zhang, S., Bellouin, N., Guttikunda, S. K., Hopke, P. K., Jacobson, M. Z., Kaiser, J. W., Klimont, Z., Lohmann, U., Schwarz, J. P., Shindell, D., Storelvmo, T., Warren, S. G., and Zender, C. S.: Bounding the role of black carbon in the climate system: A scientific assessment, J. Geophys. Res.-Atmos., 118, 5380-5552, https://doi.org/10.1002/jgrd.50171, 2013.

Cao, J.: The importance of aerosols in the earth system: science and engineering perspectives, Aerosol Sci. Eng., 1, 1-6, https://doi.org/10.1007/s41810-017-0005-1, 2017.

Cao, J.-J., Zhu, C.-S., Chow, J. C., Watson, J. G., Han, Y.-M., Wang, G.-H., Shen, Z.-X., and An, Z.-S.: Black carbon relationships with emissions and meteorology in Xi' an, China, Atmos. Res., 94, 194-202, https://doi.org/10.1016/j.atmosres.2009.05.009, 2009.

Cao, J. J., Tie, X. X., Xu, B. Q., Zhao, Z. Z., Zhu, C. S., Li, G. H., and Liu, S. X.: Measuring and modeling black carbon (BC) contamination in the SE Tibetan Plateau, J. Atmos. Chem., 67, 45-60, https://doi.org/10.1007/s10874-011-9202-5, 2010.

Chen, P., Kang, S., Bai, J., Sillanpää, M., and Li, C.: Yak dung combustion aerosols in the Tibetan Plateau: Chemical characteristics and influence on the local atmospheric environment, Atmos. Res., 156, 58-66, 2015.

Cong, Z., Kang, S., Kawamura, K., Liu, B., Wan, X., Wang, Z., Gao, S., and Fu, P.: Carbonaceous aerosols on the south edge of the Tibetan Plateau: concentrations, seasonality and sources, Atmos. Chem. Phys., 15, 1573-1584, https://doi.org/10.5194/acp15-1573-2015, 2015.

Draxler, R. R. and Rolph, G. D.: HYSPLIT (HYbrid Single-Particle Lagrangian Integrated Trajectory), Silver Spring, MD, Model access via NOAA ARL READY Website: http://www.arl.noaa.gov/ ready/hysplit4.htmlNOAAAirResourcesLaboratory (last access: March 2017), 2003.

Dyurgerov, M. B., and Meier, M. F.: Twentieth century climate change: Evidence from small glaciers, P. Natl. Acad. Sci. USA, 97, 1406-1411, https://doi.org/10.1073/pnas.97.4.1406, 2000.

Engling, G., Zhang, Y.-N., Chan, C.-Y., Sang, X.-F., Lin, M., Ho, K.-F., Li, Y.-S., Lin, C.-Y., and Lee, J. J.: Characterization and sources of aerosol particles over the southeastern Tibetan Plateau during the Southeast Asia biomass-burning season, Tellus B, 63, 117-128, https://doi.org/10.1111/j.1600-0889.2010.00512.x, 2011.

Fast, J. D., de Foy, B., Acevedo Rosas, F., Caetano, E., Carmichael, G., Emmons, L., McKenna, D., Mena, M., Skamarock, W. Tie, X., Coulter, R. L., Barnard, J. C., Wiedinmyer, C., and Madronich, S.: A meteorological overview of the MILAGRO field campaigns, Atmos. Chem. Phys., 7, 2233-2257, https://doi.org/10.5194/acp-7-2233-2007, 2007.

Gysel, M., Laborde, M., Olfert, J. S., Subramanian, R., and Grohn, A. J.: Effective density of Aquadag and fullerene soot black carbon reference materials used for SP2 calibration, Atmos. Meas. Tech., 4, 2851-2858, https://doi.org/10.5194/amt-4-2851-2011, 2011.

He, C., Li, Q., Liou, K.-N., Takano, Y., Gu, Y., Qi, L., Mao, Y., and Leung, L. R.: Black carbon radiative forcing over the Tibetan Plateau, Geophys. Res. Lett., 41, 7806-7813, https://doi.org/10.1002/2014GL062191, 2014.

Hsu, Y.-K., Holsen, T. M., and Hopke, P. K.: Comparison of hybrid receptor models to locate PCB sources in Chicago, Atmos. Environ., 37, 545-562, https://doi.org/10.1016/S13522310(02)00886-5, 2003.

Huang, X. F., Sun, T. L., Zeng, L. W., Yu, G. H., and Luan, S. J.: Black carbon aerosol characterization in a coastal city in South China using a single particle soot photometer, Atmos. Environ., 51, 21-28, https://doi.org/10.1016/j.atmosenv.2012.01.056, 2012.

Huintjes, E., Loibl, D., Lehmkuhl, F., and Schneider, C.: A modelling approach to reconstruct Little Ice Age climate from remote-sensing glacier observations in southeastern Tibet, Ann. Glaciol., 57, 359-370, https://doi.org/10.3189/2016AoG71A025, 2016.

Immerzeel, W. W., van Beek, L. P. H., and Bierkens, M. F. P.: Climate change will affect the Asian water towers, Science, 328 , 1382-1385, https://doi.org/10.1126/science.1183188, 2010.

Jacobson, M. Z.: Strong radiative heating due to the mixing state of black carbon in atmospheric aerosols, Nature, 409, 695-697, https://doi.org/10.1038/35055518, 2001.

Kang, S., Mayewski, P. A., Qin, D., Yan, Y., Zhang, D., Hou, S., and Ren, J.: Twentieth century increase of atmospheric ammonia recorded in Mount Everest ice core, J. Geophys. Res., 107, 4595, https://doi.org/10.1029/2001JD001413, 2002.

Kang, S., Wang, F., Morgenstern, U., Zhang, Y., Grigholm, B., Kaspari, S., Schwikowski, M., Ren, J., Yao, T., Qin, D., and Mayewski, P. A.: Dramatic loss of glacier accumulation area on the Tibetan Plateau revealed by ice core tritium and mercury records, The Cryosphere, 9, 1213-1222, https://doi.org/10.5194/tc-9-1213-2015, 2015.

Ke, L., Ding, X., Li, W., and Qiu, B.: Remote sensing of glacier change in the central Qinghai-Tibet Plateau and the relationship with changing climate, Remote Sens., 9, 114-133, https://doi.org/10.3390/rs9020114, 2017.

Laborde, M., Mertes, P., Zieger, P., Dommen, J., Baltensperger, U., and Gysel, M.: Sensitivity of the Single Particle Soot Photometer to different black carbon types, Atmos. Meas. Tech., 5, 10311043, https://doi.org/10.5194/amt-5-1031-2012, 2012.

Laskin, A., Laskin, J., and Nizkorodov, S. A.: Chemistry of atmospheric brown carbon, Chem. Rev., 115, 4335-4382, https://doi.org/10.1021/cr5006167, 2015. 
Lau, K. M. and Kim, K. M.: Observational relationships between aerosol and Asian monsoon rainfall, and circulation, Geophys. Res. Lett., 33, L21810, https://doi.org/10.1029/2006GL027546, 2006.

Li, C., Bosch, C., Kang, S., Andersson, A., Chen, P., Zhang, Q., Cong, Z., Chen, B., Qin, D., and Gustafsson, Ö.: Sources of black carbon to the Himalayan-Tibetan Plateau glaciers, Nat. Commun., 7, 12574, https://doi.org/10.1038/ncomms12574, 2016a.

Li, C., Yan, F., Kang, S., Chen, P., Hu, Z., Gao, S., Qu, B., and Sillanpää, M.: Light absorption characteristics of carbonaceous aerosols in two remote stations of the southern fringe of the Tibetan Plateau, China, Atmos. Environ., 143, 79-85, 2016 b.

Li, C., Chen, P., Kang, S., Yan, F., Hu, Z., Qu, B., and Sillanpää, M.: Concentrations and light absorption characteristics of carbonaceous aerosol in $\mathrm{PM}_{2.5}$ and $\mathrm{PM}_{10}$ of Lhasa city, the Tibetan Plateau, Atmos. Environ., 127, 340-346, 2016c.

Li, C., Yan, F., Kang, S., Chen, P., Han, X., Hu, Z., Zhang, G., Hong, Y., Gao, S., Qu, B., Zhu, Z., Li, J., Chen, B., and Sillanpää, M.: Re-evaluating black carbon in the Himalayas and the Tibetan Plateau: concentrations and deposition, Atmos. Chem. Phys., 17, 11899-11912, https://doi.org/10.5194/acp-17-118992017, 2017.

Liu, D., Flynn, M., Gysel, M., Targino, A., Crawford, I., Bower, K., Choularton, T., Juranyi, Z., Steinbacher, M., Hueglin, C., Curtius, J., Kampus, M., Petzold, A., Weingartner, E., Baltensperger, U., and Coe, H.: Single particle characterization of black carbon aerosols at a tropospheric alpine site in Switzerland, Atmos. Chem. Phys., 10, 7389-7407, https://doi.org/10.5194/acp10-7389-2010, 2010.

Liu, S., Aiken, A. C., Gorkowski, K., Dubey, M. K., Cappa, C. D., Williams, L. R., Herndon, S. C., Massoli, P., Fortner, E. C., Chhabra, P. S., Brooks, W. A., Onasch, T. B., Jayne, J. T., Worsnop, D. R., China, S., Sharma, N., Mazzoleni, C., Xu, L., Ng, N. L., Liu, D., Allan, J. D., Lee, J. D., Fleming, Z. L., Mohr, C., Zotter, P., Szidat, S., and Prevot, A. S. H.: Enhanced light absorption by mixed source black and brown carbon particles in UK winter, Nat. Commun., 6, 8435, https://doi.org/10.1038/ncomms9435, 2015.

Loibl, D., Lehmkuhl, F., and Grießinger, J.: Reconstructing glacier retreat since the Little Ice Age in SE Tibet by glacier mapping and equilibrium line altitude calculation, Geomorphology, 214, 22-39, https://doi.org/10.1016/j.geomorph.2014.03.018, 2014.

Lu, Z., Streets, D. G., Zhang, Q., and Wang, S.: A novel backtrajectory analysis of the origin of black carbon transported to the Himalayas and Tibetan Plateau during 1996-2010, Geophys. Res. Lett., 39, L01809, https://doi.org/10.1029/2011GL049903, 2012.

Ma, J. Z., Tang, J., Li, S. M., and Jacobson, M. Z.: Size distributions of ionic aerosols measured at Waliguan Observatory: Implication for nitrate gas-to-particle transfer processes in the free troposphere, J. Geophys. Res., 108, 4541, https://doi.org/10.1029/2002JD003356, 2003.

Marinoni, A., Cristofanelli, P., Laj, P., Duchi, R., Calzolari, F., Decesari, S., Sellegri, K., Vuillermoz, E., Verza, G. P., Villani, P., and Bonasoni, P.: Aerosol mass and black carbon concentrations, a two year record at NCO-P (5079 m, Southern Himalayas), Atmos. Chem. Phys., 10, 8551-8562, https://doi.org/10.5194/acp10-8551-2010, 2010.
McMeeking, G. R., Morgan, W. T., Flynn, M., Highwood, E. J., Turnbull, K., Haywood, J., and Coe, H.: Black carbon aerosol mixing state, organic aerosols and aerosol optical properties over the United Kingdom, Atmos. Chem. Phys., 11, 9037-9052, https://doi.org/10.5194/acp-11-9037-2011, 2011.

Moosmüller, H., Chakrabarty, R. K., Ehlers, K. M., and Arnott, W. P.: Absorption Ångström coefficient, brown carbon, and aerosols: basic concepts, bulk matter, and spherical particles, Atmos. Chem. Phys., 11, 1217-1225, https://doi.org/10.5194/acp11-1217-2011, 2011.

Pant, P., Hegde, P., Dumka, U. C., Sagar, R., Satheesh, S. K., Moorthy, K. K., Saha, A., and Srivastava, M. K.: Aerosol characteristics at a high-altitude location in central Himalayas: Optical properties and radiative forcing, J. Geophys. Res., 111, D17206, https://doi.org/10.1029/2005JD006768, 2006.

Peng, J. F., Hu, M., Guo, S., Du, Z. F., Zheng, J., Shang, D. J., Zamora, M. L., Zeng, L. M., Shao, M., Wu, Y. S., Zheng, J., Wang, Y., Glen, C. R., Collins, D. R., Molina, M. J., and Zhang, R. Y.: Markedly enhanced absorption and direct radiative forcing of black carbon under polluted urban environments, P. Natl. Acad. Sci. USA, 113, 4266-4271, https://doi.org/10.1073/pnas.1602310113, 2016.

Petzold, A., Ogren, J. A., Fiebig, M., Laj, P., Li, S.-M., Baltensperger, U., Holzer-Popp, T., Kinne, S., Pappalardo, G., Sugimoto, N., Wehrli, C., Wiedensohler, A., and Zhang, X.-Y.: Recommendations for reporting "black carbon" measurements, Atmos. Chem. Phys., 13, 8365-8379, https://doi.org/10.5194/acp13-8365-2013, 2013.

Ping, X., Jiang, Z., and Li, C.: Status and future perspectives of energy consumption and its ecological impacts in the Qinghai-Tibet region, Renew. Sustain. Energ. Rev., 15, 514-523, https://doi.org/10.1016/j.rser.2010.07.037, 2011.

Raatikainen, T., Brus, D., Hyvärinen, A. P., Svensson, J., Asmi, E., and Lihavainen, H.: Black carbon concentrations and mixing state in the Finnish Arctic, Atmos. Chem. Phys., 15, 1005710070, https://doi.org/10.5194/acp-15-10057-2015, 2015.

Raatikainen, T., Brus, D., Hooda, R. K., Hyvarinen, A.-P., Asmi, E., Sharma, V. P., Arola, A., and Lihavainen, H.: Size-selected black carbon mass distributions and mixing state in polluted and clean environments of northern India, Atmos. Chem. Phys., 17, 371-383, https://doi.org/10.5194/acp-17-371-2017, 2017.

Ramanathan, V. and Carmichael, G.: Global and regional climate changes due to black carbon, Nat. Geosci., 1, 221-227, https://doi.org/10.1038/ngeo156, 2008.

Sahu, L. K., Kondo, Y., Moteki, N., Takegawa, N., Zhao, Y., Cubison, M. J., Jimenez, J. L., Vay, S., Diskin, G. S., Wisthaler, A., Mikoviny, T., Huey, L. G., Weinheimer, A. J., and Knapp, D. J.: Emission characteristics of black carbon in anthropogenic and biomass burning plumes over California during ARCTAS-CARB 2008, J. Geophys. Res., 117, D16302, https://doi.org/10.1029/2011JD017401, 2012.

Schwarz, J. P., Gao, R. S., Fahey, D. W., Thomson, D. S., Watts, L. A., Wilson, J. C., Reeves, J. M., Darbeheshti, M., Baumgardner, D. G., Kok, G. L., Chung, S. H., Schulz, M., Hendricks, J., Lauer, A., Karcher, B., Slowik, J. G., Rosenlof, K. H., Thompson, T. L., Langford, A. O., Loewenstein, M., and Aikin, K. C.: Single-particle measurements of midlatitude black carbon and light-scattering aerosols from the boundary 
layer to the lower stratosphere, J. Geophys. Res., 111, D16207, https://doi.org/10.1029/2006JD007076, 2006.

Schwarz, J. P., Gao, R. S., Spackman, J. R., Watts, L. A., Thomson, D. S., Fahey, D. W., Ryerson, T. B., Peischl, J., Holloway, J. S., Trainer, M., Frost, G. J., Baynard, T., Lack, D. A., de Gouw, J. A., Warneke, C., and Del Negro, L. A.: Measurement of the mixing state, mass, and optical size of individual black carbon particles in urban and biomass burning emissions, Geophys. Res. Lett., 35, L13810, https://doi.org/10.1029/2008GL033968, 2008.

Sirois, A. and Bottenheim, J. W.: Use of backward trajectories to interpret the 5-year record of PAN and $\mathrm{O} 3$ ambient air concentrations at Kejimkujik National Park, Nova Scotia, J. Geophys. Res., 100, 2867-2881, https://doi.org/10.1029/94JD02951, 1995.

Slowik, J. G., Cross, E. S., Han, J. H., Davidovits, P., Onasch, T. B., Jayne, J. T., Williams, L. R., Canagaratna, M. R., Worsnop, D. R., Chakrabarty, R. K., Moosmuller, H., Arnott, W. P., Schwarz, J. P., Gao, R. S., Fahey, D. W., Kok, G. L., and Petzold, A.: An inter-comparison of instruments measuring black carbon content of soot particles, Aerosol Sci. Tech., 41, 295-314, https://doi.org/10.1080/02786820701197078, 2007.

Stone, E. A., Schauer, J. J., Pradhan, B. B., Dangol, P. M., Habib, G., Venkataraman, C., and Ramanathan, V.: Characterization of emissions from South Asian biofuels and application to source apportionment of carbonaceous aerosol in the Himalayas, J. Geophys. Res., 115, D06301, https://doi.org/10.1029/2009JD011881, 2010.

Taylor, J. W., Allan, J. D., Allen, G., Coe, H., Williams, P. I., Flynn, M. J., Le Breton, M., Muller, J. B. A., Percival, C. J., Oram, D., Forster, G., Lee, J. D., Rickard, A. R., Parrington, M., and Palmer, P. I.: Size-dependent wet removal of black carbon in Canadian biomass burning plumes, Atmos. Chem. Phys., 14, 13755-13771, https://doi.org/10.5194/acp-14-137552014, 2014.

Vadrevu, K. P., Ohara, T., and Justice, C.: Air pollution in Asia, Environ. Pollut., 195, 233-235, https://doi.org/10.1016/j.envpol.2014.09.006, 2014.

Virkkula, A., Makela, T., Hillamo, R., Yli-Tuomi, T., Hirsikko, A., Hameri, K., and Koponen, I. K.: A simple procedure for correcting loading effects of aethalometer data, J. Air Waste Manage. Assoc., 57, 1214-1222, https://doi.org/10.3155/10473289.57.10.1214, 2007.

Wan, X., Kang, S., Wang, Y., Xin, J., Liu, B., Guo, Y., Wen, T., Zhang, G., and Cong, Z.: Size distribution of carbonaceous aerosols at a high-altitude site on the central Tibetan Plateau (Nam Co Station, 4730 ma.s.1.), Atmos. Res., 153, 155-164, https://doi.org/10.1016/j.atmosres.2014.08.008, 2015.

Wang, M., Xu, B., Wang, N., Cao, J., Tie, X., Wang, H., Zhu, C., and Yang, W.: Two distinct patterns of seasonal variation of airborne black carbon over Tibetan Plateau, Sci. Total Environ., 573, 1041-1052, https://doi.org/10.1016/j.scitotenv.2016.08.184, 2016.

Wang, Q., Schwarz, J. P., Cao, J., Gao, R., Fahey, D. W., Hu, T., Huang, R. J., Han, Y., and Shen, Z.: Black carbon aerosol characterization in a remote area of Qinghai-Tibetan Plateau, western China, Sci. Total Environ., 479-480, 151-158, https://doi.org/10.1016/j.scitotenv.2014.01.098, 2014.

Wang, Q., Huang, R.-J., Zhao, Z., Zhang, N., Wang, Y., Ni, H., Tie, X., Han, Y., Zhuang, M., Wang, M., Zhang, J., Zhang, X., Dusek, U., and Cao, J.: Size distribution and mixing state of refractory black carbon aerosol from a coastal city in South China, Atmos. Res., 181, 163-171, https://doi.org/10.1016/j.atmosres.2016.06.022, 2016a.

Wang, Q., Huang, R.-J., Zhao, Z., Cao, J., Ni, H., Tie, X., Zhao, S., Su, X., Han, Y., Shen, Z., Wang, Y., Zhang, N., Zhou, Y., and Corbin, J. C.: Physicochemical characteristics of black carbon aerosol and its radiative impact in a polluted urban area of China, J. Geophys. Res.-Atmos., 121, 12505-12519, https://doi.org/10.1002/2016JD024748, 2016 b.

Wang, Q., Zhao, Z., Tian, J., Zhu, C., Ni, H., Zhang, Y., Zhang, N., Shen, Z., Han, Y., and Cao, J.: Seasonal transport and dry deposition of black carbon aerosol in the Southeastern Tibetan Plateau, Aerosol Sci. Eng., 1, 160-168, https://doi.org/10.1007/s41810017-0016-y, 2017.

Wang, Q. Y., Huang, R. J., Cao, J. J., Tie, X. X., Ni, H. Y., Zhou, Y. Q., Han, Y. M., Hu, T. F., Zhu, C. S., Feng, T., Li, N., and Li, J. D.: Black carbon aerosol in winter northeastern Qinghai-Tibetan Plateau, China: the source, mixing state and optical property, Atmos. Chem. Phys., 15, 13059-13069, https://doi.org/10.5194/acp-15-13059-2015, 2015a.

Wang, Q. Y., Gao, R., Cao, J., Schwarz, J., Fahey, D., Shen, Z., Hu, T., Wang, P., Xu, X., and Huang, R.-J.: Observations of high level of ozone at Qinghai Lake basin in the northeastern QinghaiTibetan Plateau, western China, J. Atmos. Chem., 72, 19-26, https://doi.org/10.1007/s10874-015-9301-9, 2015b.

Wang, Y. Q., Zhang, X. Y., and Draxler, R. R.: TrajStat: GISbased software that uses various trajectory statistical analysis methods to identify potential sources from long-term air pollution measurement data, Environ. Model. Softw., 24, 938-939, https://doi.org/10.1016/j.envsoft.2009.01.004, 2009.

White, W., Anderson, J., Blumenthal, D., Husar, R., Gillani, N., Husar, J., and Wilson, W.: Formation and transport of secondary air pollutants: ozone and aerosols in the St. Louis urban plume, Science, 194, 187-189, https://doi.org/10.1126/science.959846, 1976.

Wu, Y., Zhang, R., Tian, P., Tao, J., Hsu, S. C., Yan, P., Wang, Q., Cao, J., Zhang, X., and Xia, X.: Effect of ambient humidity on the light absorption amplification of black carbon in Beijing during January 2013, Atmos. Environ., 124, 217-223, https://doi.org/10.1016/j.atmosenv.2015.04.041, 2016.

Xu, B. Q., Cao, J. J., Hansen, J., Yao, T. D., Joswia, D. R., Wang, N. L., Wu, G. J., Wang, M., Zhao, H. B., Yang, W., Liu, X. Q., and He, J. Q.: Black soot and the survival of Tibetan glaciers, P. Natl. Acad. Sci. USA, 106, 22114-22118, https://doi.org/10.1073/pnas.0910444106, 2009.

Yao, T., Ren, J., and Xu, B.: Map of glaciers and lakes on the Tibetan Plateau and the surroundings, Xi' an Cartographic Publishing House, Xi'an, 2008.

Yao, T., Thompson, L., Yang, W., Yu, W., Gao, Y., Guo, X., Yang, X., Duan, K., Zhao, H., Xu, B., Pu, J., Lu, A., Xiang, Y., Kattel, D. B., and Joswiak, D.: Different glacier status with atmospheric circulations in Tibetan Plateau and surroundings, Nat. Clim. Change, 2, 663-667, https://doi.org/10.1038/nclimate1580, 2012.

Zhang, M., Wang, S., Li, Z., and Wang, F.: Glacier area shrinkage in China and its climatic background during the past half century, J. Geogr. Sci., 22, 15-28, https://doi.org/10.1007/s11442012-0908-3, 2012. 
Zhang, Q., Streets, D. G., Carmichael, G. R., He, K. B., Huo, H., Kannari, A., Klimont, Z., Park, I. S., Reddy, S., Fu, J. S., Chen, D., Duan, L., Lei, Y., Wang, L. T., and Yao, Z. L.: Asian emissions in 2006 for the NASA INTEX-B mission, Atmos. Chem. Phys., 9, 5131-5153, https://doi.org/10.5194/acp-9-5131-2009, 2009.

Zhang, R., Wang, H., Qian, Y., Rasch, P. J., Easter, R. C., Ma, P. L., Singh, B., Huang, J., and Fu, Q.: Quantifying sources, transport, deposition, and radiative forcing of black carbon over the Himalayas and Tibetan Plateau, Atmos. Chem. Phys., 15, 62056223, https://doi.org/10.5194/acp-15-6205-2015, 2015.

Zhang, X., Ming, J., Li, Z., Wang, F., and Zhang, G.: The online measured black carbon aerosol and source orientations in the Nam Co region, Tibet, Environ. Sci. Pollut. Res., 24, 2502125033, 2017.

Zhang, Y., Zhang, Q., Cheng, Y., Su, H., Kecorius, S., Wang, Z., Wu, Z., Hu, M., Zhu, T., Wiedensohler, A., and He, K.: Measuring the morphology and density of internally mixed black carbon with SP2 and VTDMA: new insight into the absorption enhancement of black carbon in the atmosphere, Atmos. Meas. Tech., 9, 1833-1843, https://doi.org/10.5194/amt-9-1833-2016, 2016.
Zhang, Y., Kang, S., Li, C., Gao, T., Cong, Z., Sprenger, M., Liu, Y., Li, X., Guo, J., Sillanpää, M., Wang, K., Chen, J., Li, Y., and Sun, S.: Characteristics of black carbon in snow from Laohugou No. 12 glacier on the northern Tibetan Plateau, Sci. Total Environ., 607-608, 1237-1249, https://doi.org/10.1016/j.scitotenv.2017.07.100, 2017.

Zhao, S., Ming, J., Xiao, C., Sun, W., and Qin, X.: A preliminary study on measurements of black carbon in the atmosphere of northwest Qilian Shan, J. Environ. Sci., 24, 152-159, https://doi.org/10.1016/S1001-0742(11)60739-0, 2012.

Zhao, S., Tie, X., Long, X., and Cao, J.: Impacts of Himalayas on black carbon over the Tibetan Plateau during summer monsoon, Sci. Total Environ., 598, 307-318, https://doi.org/10.1016/j.scitotenv.2017.04.101, 2017.

Zhao, Z., Wang, Q., Xu, B., Shen, Z., Huang, R., Zhu, C., Su, X., Zhao, S., Long, X., Liu, S., and Cao, J.: Black carbon aerosol and its radiative impact at a high-altitude remote site on the southeastern Tibet Plateau, J. Geophys. Res.-Atmos., 122, 1-16, https://doi.org/10.1002/2016JD026032, 2017.

Zhu, C.-S., Cao, J.-J., Xu, B.-Q., Huang, R.-J., Wang, P., Ho, K.-F., Shen, Z.-X., Liu, S.-X., Han, Y.-M., Tie, X.-X., Zhao, Z.-Z., and Chen, L. W. A.: Black carbon aerosols at Mt. Muztagh Ata, a high-altitude location in the Western Tibetan Plateau, Aerosol Air Qual. Res., 16, 752-763, https://doi.org/10.4209/aaqr.2015.04.0255, 2016. 